\title{
KNJIŽEVNE REVOLUCIJE: NASLIJEĐE AVANGARDE U HRVATSKOJ KNJIŽEVNOSTI
}

19. rujna 2019.

Vijećnica Filozofskog fakulteta u Zagrebu

Marina Protrka Štimec: Dobar dan svima. Hvala vam svima što ste došli. Ja sam Marina Protrka Štimec, profesorica na Odsjeku za kroatistiku ovdje na Fakultetu i voditeljica projekta Hrvatske zaklade za znanost "Književne revolucije", s čijom temom danas organiziramo ovu tribinu u sklopu aktivnosti na projektu. Osim mene na projektu su još suradnici docentica Zrinka Božić Blanuša, također s kroatistike, docentica Andrea Milanko, također s naše kroatistike, s iste katedre, te asistent Zvonimir Glavaš i naša novakinja na projektu Mirela Dakić. Osim kroatističke ekipe tu je i kolegica doktorica Ana Tomljenović s Odsjeka za komparativnu književnost i izvanredni profesor Aleksandar Mijatović s riječke kroatistike. Dakle, taj naš mali tim dao si je zadatak da krene od onoga što se o avangardi dosad u hrvatskoj i široj znanosti o književnosti pisalo. To nam je neka polazišna točka, nešto što je ostalo kao znanstveno naslijeđe avangarde, da od toga krenemo i dalje istražujemo.

Pod tim naslijeđem mislimo i na teorijsko promišljanje, metodološki teorijski okvir kojim se operiralo, ali također i na šira teorijska i književnopovijesna istraživanja i spoznaje koje avangardu zadnjih desetljeća otkrivaju na novi način. Prije svega riječ je o odnosu između estetske autonomije i političkog, odnosno o emancipatorskom potencijalu književnosti unutar avangarde, ali i šire. Dakle, o književnosti koja nastaje nakon što se s avangardnom krenulo dalje ili nakon što je ostavljena iza. Zanimat će nas na koji je način avangarda utjecala na to kako se nastavilo pisati i istraživati, unutar polja književnosti i unutar teorijskog polja. Ono što nas u tom balansu između estetske autonomije i emancipatorskih praksi svakako zanima jest polje književnosti, načini na koje se književnost stvara i percipira, sve ono što označava i politiku, i estetiku, i poetiku, ideologiju i tako dalje. Također će nas zanimati odnos prema prošlosti i tradiciji unutar pokreta, ali i 
$\mathrm{u}$ istraživanju, logika temporalnosti inherentna avangardnim pokretima te ideologija koja stoji uz ove promjene: razumijevanje građanskih i nacionalnih narativa, kao i projekti političkih zajednica. Zanimat će nas i dominantni tip racionalnosti, odnosno prevladavajuće simboličke prakse pod kojima se književnost odvija i u kojima se pojavljuje. Cilj nam je istražiti, odnosno doći do koherentnog tipa teorijskog i metodološkog znanja koje će razumjeti i analizirati koncepte književnih revolucija, dakle ne samo od avangarde nego uključujući i ono što joj je prethodilo, načine na koje su različite vrste revolucija utjecale na književno-umjetničko polje, od Francuske, Oktobarske i drugih. Također nam je posebno zanimljiv status malih književnosti, i tu će nam danas pomoći naši sugovornici na tribini, ali očekujemo pomoć i od vas, dakle da čujemo vaša razmišljanja, ono što se vama čini da je zanimljivo, kako vi razumijete određene fenomene - na koji način takozvane male književnosti funkcioniraju u razumijevanju i konstituiranju otpora, refleksije, autonomije, kako se unutar književnog polja razvijaju različite vrste otpora, bilo eksplicitno bilo otpora koji se pretvara u otpor forme, recimo kod Krleže, Begovića, Desnice i drugdje. Također će nas zanimati specifični oblici otpora koji se razvijaju u strategijama ženskog pisma, dakle i u praksi, ali i

$136 \mathrm{u}$ teoriji, te, sukladno pojedinačnim interesima istraživača, psihoanalitički način razumijevanja svih tih fenomena. Ono čime bismo voljeli doprinijeti u ovom poslu jest da ponudimo novi opis poetike kanonskih pisaca, uključujući sve žanrove, od pjesništva, proze i drame hrvatskog modernizma, da iznađemo nove teorijske i metodološke strategije, odnosno platforme za daljnja istraživanja tih i srodnih tema te da iskoristimo znanja, sve ono što nam je dostupno u svjetlu novih teorijskih pristupa, i da nam ta teorijska znanja budu posložena, da možemo s njima redefinirati i repozicionirati sam pojam avangarde.

Hvala vam na pozornosti. Sada bih zamolila naše sugovornike, sudionike tribine, da nam pomognu u analiziranju tih ključnih točki. S nama je danas, mnogima od vas poznat, doktor znanosti Predrag Brebanović, docent na Filološkom fakultetu Univerziteta u Beogradu i autor niza zapaženih knjiga i studija, nama danas posebno zanimljive Avangarde Krležiane, koja je kao "pismo ne o avangardi" objavljena u Zagrebu, a posvećena je odnosu Miroslava Krleže i avangarde. To je knjiga koja se koristi strategijom srodnom mikročitanjima, odnosno čitanjima odozdo, rekonstruirajući velike fenomene i pomake koji se tiču avangarde, jugoslavenskog prostora i načina na koje se ti fenomeni konstituiraju u vrijeme kada Krleža stvara, ali zapravo su relevantni i danas. Sljedeća je naša sudionica profesorica Tatjana Jukić, koju također poznajete, s Odsjeka za anglistiku, engleski jezik i književnost, 
redovita profesorica, predstojnica Katedre i autorica koja zapravo i nama iz perspektive kroatistike nudi teorijske i interpretativno poticajne uvide. Od njezinih publikacija te znanstvenih i nastavnih interesa istaknuli bismo njezinu drugu knjigu, Revolucija i melankolija: granice pamćenja brvatske književnosti, koja je već 2011. postavila neke od zanimljivih i intrigantnih tema o kojima će i danas biti riječi, a tiču se elemenata revolucionarnog i avangardnog, upućujući na načine spajanja i rastvaranja te veze. S nama je i kolegica s Fakulteta, doktorica Danijela Lugarić Vukas, docentica s Odsjeka za istočnoslavenske jezike i književnosti, predstojnica Zavoda za znanost o književnosti, koji nam je danas izuzetno bitan jer je objavio niz važnih i za nas nezaobilaznih izdanja. Ona uređuje sada redizajniranu treću seriju Biblioteke "L" i danas će nas podsjetiti na ono što se radilo unutar Zavoda i što se o avangardi dosada pisalo, pogotovo kada je riječ o Pojmovniku ruske avangarde. Objavila je niz knjiga, uredila niz publikacija koje se tiču avangarde i postsocijalizma, među kojima valja istaknuti nedavno objavljeni zbornik Kulturna povijest Oktobarske revolucije. I četvrti sudionik naše tribine, kolega doktor znanosti Branislav Oblučar, docent na Odsjeku za komparativnu književnost, niz godina bavi se avangardom u svom znanstvenom i nastavnom radu. Objavio je niz članaka o Ivšiću, Galoviću, Ujeviću, o avangardnom manifestu i također već godinama izvodi kolegije koji za svoju osnovnu temu imaju ili europsku avangardu ili hrvatsku književnu avangardu u europskom kontekstu.

Hvala vam na pozornosti. Dajem riječ našoj kolegici Danijeli Lugarić Vukas koja će krenuti od onoga od čega i mi zapravo krećemo, a to su izdanja i aktivnosti Zavoda.

Danijela Lugarić Vukas: Dobar dan svima. Zahvaljujem prije svega na pozivu. Ovdje sam pozvana da govorim kao predstojnica Zavoda, kao urednica zbornika o Oktobarskoj revoluciji, i mislim da će moje izlaganje biti puno više faktografsko u odnosu na izlaganje profesorice Jukić i kolege Brebanovića, ali nadam se da će svejedno biti zanimljivo. Zavod za znanost o književnosti organizirao je skupove posvećene ruskoj avangardi i položio temelje za daljnja istraživanja avangarde, ne samo u ruskoj književnosti nego i u drugim nacionalnim sredinama. Jedan od prvih istraživača ruske avangarde, s kojim je Aleksandar Flaker najuže surađivao, Miklós Szábolcsi, uostalom govori da avangarda implicira složeno jedinstvo, ona je grupa pravaca u međuprostoru. Dakle, tom izjavom mađarskog istraživača dijelom se daje odgovor na pitanje o tome o kojoj/čijoj nacionalnoj književnosti govorimo kada govorimo o avangardi: kada govorimo o avangardi u nekoj 
nacionalnoj književnosti, govorimo istovremeno i o ruskoj, ali i o drugim nacionalnim književnostima.

Moje će se izlaganje grupirati oko pitanja postavljenih ovom tribinom. Što je avangarda danas? Postoji li u književnosti revolucija koja traje? Književnost kao privilegiran prostor političke participacije: utopija ili realnost? Što se događa s avangardom kada ude u znanosti? Svojim bih izlaganjem potaknula suradnike na projektu da promotre koliko se iskorištava intelektualno naslijeđe u domaćim proučavanjima avangarde te da promotre koliko se na ta istraživanja uopće vrijedi nadovezivati i u kojim aspektima. Izlaganje je podijeljeno u nekoliko koraka. Prvo, zanima me prvenstvo zagrebačke znanstveno-književne sredine u proučavanju avangarde. Drugo, zanima me odnos književnosti i ideologije, estetskog i političkog upravo u Pojmovnicima ruske avangarde. I, treći korak, u vezi s drugim korakom - promotrit ću status revolucije, Oktobarske, socijalne, u pojmovničkim pristupima avangardi, i to u dijakronijskom nizu, od nultog Pojmovnika, to je Pojmovnik koji je objavljen u Umjetnosti riječi 1981. godine (dakle to nije prvi, nego nulti), do posljednjeg, desetog Pojmovnika. Svi pretpostavljamo da je bilo devet Pojmovnika, što nije točno - postoji deseti Pojmovnik, koji se 138 nalazi u inače vrlo oskudnoj zavodskoj arhivi. Taj zbornik je pripremljen za tisak, prelomljen, i čak na marginama postoje i lektorski komentari. Koliko mi je poznato, ovo je prvi put da netko u znanstvenoj javnosti govori o tom zborniku i ja ću se u nekim dijelovima referirati na njega.

Prvo pitanje: je li rodno mjesto znanstvene avangarde Zagreb, odnosno Filozofski fakultet Sveučilišta u Zagrebu? To da je rodno mjesto, znanstvena domovina avangarde Zagreb nekako je opće mjesto u domaćim historiografskim promišljanjima avangarde. Recimo, Bogdan Kosanović u časopisu Dnevnik piše osvrt na deseti, jubilarni sastanak pojmovničara u studenom 1990. i laska mu bombastičnim naslovom "Svetsko otkrivanje ruske avangarde". Međutim, ja bih se ovdje referirala - to je povezano dakle i s idejom Pojmovnika, ali i s drugim radovima istraživača oko Aleksandra Flakera, od Dubravke Oraić-Tolić, Žive Benčić Primc, Josipa Užarevića, Zdenke Matek Šmit i tako dalje - na uvodni tekst Aleksandra Flakera koji se nalazi u tom neobjavljenom desetom Pojmovniku i koji je pisan u svibnju 1992. godine (riječ je o jedinom datiranom tekstu u Pojmovniku). Tu se navodi da "povijest zajedničkog rada na pitanjima ruske avangarde nije od nas u Zagrebu počela niti će s nama završiti. Kako je to jednom na opatijskom skupu, čak s prijekorom, primijetila pokojna Zara Minc [to je jedna od istraživačica u tartuškom krugu i supruga Jurija Lotmana], prvi se međunarodni susret s temom ruske avangarde 1920-ih godina održao u jednoj planinarskoj kući 
nedaleko od Bratislave u listopadu 1967. pod vodstvom čeških i slovačkih rusista i uz sudjelovanje skupine iz Tartua, kao i rusista iz Italije, Njemačke, Austrije i Hrvatske". On nadalje u tom tekstu navodi da je upravo ta konferencija 1967. godine odredila mogućnost korištenja pojma koji je već dobio svoje mjesto u češkoj znanosti i smatrala ga je prikladnim u proučavanju ruske književnosti. Dvije godine kasnije, 1969. godine, češki su slavisti organizirali još jedan susret, što je, povijesno gledano, zanimljiv podatak jer je to bilo vrijeme politički vrlo nesklono kakvim nekanoniziranim oblicima umjetnosti (godinu ranije, 1968, sovjetski tenkovi ulaze u Prag). Drugi susret 1969. godine nije održan pod nazivom/temom ruske avangarde, nego je bio posvećen tematici književnih normi 1930-ih. Kao što znamo, 1930. godine se ubija Majakovskij - i ta se godina smatra simboličkim krajem avangarde. Harmsu već 1927, primjerice, razočarani Malevič poklanja svoju knjigu s posvetom "Idite i zaustavite progres". Dakle, tu se već sami vodeći avangardisti odriču ideje optimalne projekcije koja je bila konstitutivna za njihovu beskompromisnu vjeru u budućnost. Flaker navodi dalje u tom uvodnom tekstu da je češka rusistika ubrzo nakon toga razjurena te da je jedan od vodećih zagovornika proučavatelja avangarde dobio otkaz i počeo raditi u građevinskom poduzeću. Nakon toga se središte proučavanja seli u Budimpeštu, a zagrebački Zavod osnažuje veze s Budimpeštom.

Flakerov prvi tekst objavljen na tu temu, u talijanskom časopisu 1971. godine, kako sam autor navodi, bio je nastavak rada tamo gdje su stali češki kolege, koje je omela ideološka zabrana rada na tom području. Prvo savjetovanje (upozorila bih da ću u izlaganju koristiti pojmove poput savjetovanja ili zasjedanja zbog toga što su to bili službeni nazivi tih susreta u ono vrijeme, nikada se nije govorilo o skupovima ili konferencijama, čak su postojale i zapisničarke) održano je 1977. godine pod nazivom "Književnost, avangarda i revolucija", uz uvodne riječi Miroslava Bekera i Josipa Badalića te sudjelovanje niza inozemnih predavača. Program je tiskan, kao što možete vidjeti, na Plamenu, s grafičkim rješenjem Ljube Babića, čime se naglašavala komparativnost istraživačke inicijative. Tim je susretom, čiji su referati objavljeni u Umjetnosti riječi (o čemu ću govoriti kasnije), stvorena jezgra buduće istraživačke skupine. Naglasila bih da su ta savjetovanja bila u potpunosti financirana državnim sredstvima. Dakle, s jedne strane uprava Fakulteta, Zavod za znanost o književnosti, a s druge strane Republička samoupravna interesna zajednica za znanstveni rad Socijalističke Republike Hrvatske.

U tom uvodnom tekstu Flaker ističe da su dvije knjige bile konstitutivne u metodološkom smislu za pristup avangardi: knjiga Umjetnicki smisao 
i evolucije poetskih sustava Igora Smirnova i, drugo, Ruski formalizam Aagea Hansen-Lövea (to je njegova doktorska disertacija koja je 1980. godine objavljena kao knjiga). Zašto to spominjem? Zbog toga što te dvije knjige tretiraju književnost i umjetnost u estetskoj autonomnosti, to je njihovo temeljno obilježje. Druga stvar zbog čega je važna posebno knjiga Aagea Hansen-Lövea je to što je sam žanr pojmovnika odabran upravo zbog svoje sličnosti s tom prvotno zadanom koncepcijom pojma avangarde, koja načelno nije vodila računa o drugome osim o strukturi tekstova te se stalno isticalo da je upravo ta knjiga ponudila temeljne pojmove kojima će se u budućnosti projekt baviti. Premda Flakerov uvodnik iz 1992. godine daje naslutiti da je do prekida u sustavnom bavljenju ruskom avangardom došlo zbog toga što je ta tema 1990. godine postala toliko popularnom da je istraživačima prestala biti analitički intrigantnom, izgubila je svoju znanstvenu auru, teško se oteti dojmu da su i neposredne političke okolnosti ipak odigrale koliko-toliko značajnu ulogu, jer 1993. godine nije promijenjen samo naziv - dakle ne više Pojmovnik ruske avangarde, nego Zagrebacki pojmovnik kulture (pod tim se nazivom i naši današnji susreti odvijaju) - nego je promijenjeno i vrijeme održavanja susreta. Dakle, ranije je to bio studeni, i prvi susret održan je 140 upravo kao 60. obljetnica obilježavanja Oktobarske revolucije. Sada je vrijeme održavanja bio svibanj, odnosno Prvi maj, Dan rada. Dva programa, pronađena u zavodskoj arhivi, zanimljivo ilustriraju da je politički moment ipak odigrao važnu ulogu: jedan na kojem piše da je riječ o dvanaestom Pojmovniku i drugi na kojem je netko prebrisao korektorom to 12 , kao da se tim činom htjelo raskinuti s kontinuitetom u cijelom projektu. Dakle, jedna strana htjela je naglasiti taj kontinuitet, a druga ga je htjela prekinuti. Taj Pojmovnik održan je 1993. godine od 1. do 3. svibnja, naziv je "Totalitarna umjetnost", što je samo po sebi indikativno zbog toga što je Pojmovnik upravo htio promotriti rusku avangardu u estetskoj autonomnosti. Jedna isto tako možda zanimljiva informacija - taj susret nije više bio financiran državnim sredstvima, nego inozemnim fondacijama, Open Society Fund, Austrijski kulturni forum i Goethe-Institut. U neobjavljenoj recenziji toga zbornika (također neobjavljenog) Aleksandar Flaker piše 1994. godine da "znamo da su pouke ruskog totalitarizma vrijedne i izvan područja koje je pretrpjelo rusku sovjetsku hegemoniju, pa priloženi radovi hrvatskih, njemačkih i austrijskih znanstvenika nimalo slučajno teže ne toliko registraciji činjenica koliko teorijskom osmišljavanju književnih procesa koji su od avangardizma vodili prema totalitarnim rješenjima i metodama". Slične ideje o tome da se avangarda nalazi na jednom kraju linije na čijem se drugom kraju nalaze totalitarna rješenja i metodologije možemo naći i kod Borisa Groysa; dakle 
on navodi da postavimo pitanje koje se redovito nameće u proučavanjima naslijeđa avangarde, a to je pitanje o odnosima književnosti i ideologije, estetskog i političkog.

Koje odgovore na to pitanje nudi Pojmovnik ruske avangarde? Ponovno ću se referirati na uvodnik u deseti Pojmovnik. Flaker piše "na početku je i u nas stajala riječ". O tome piše i 1992. godine. "Prvenstveno nas je zanimala terminologija koju su razradili formalisti kao temeljni pouzdani teoretičari avangarde, a zatim i Bahtinovi pojmovi, a tek u drugom redu obrađeni su i protumačeni pojmovi koje su stvorili sami nosioci avangardnih tekstova, Hljebnikov, Malevič, Filonov.” Nadalje, Flaker navodi, "katastrofično rasulo cijelog jednog sustava od Labe do Vladivostoka, od Havane do Pekinga, ali i od Triglava do Đevdelije, dovodi ujedno do potrebe retrospektivnog revidiranja cijelog sustava vrijednosti, i to ne samo svjetonazorskoga. Koliko smo na taj izazov kao znanstvenici koji se bave književnim tekstovima spremni odgovoriti, pitanje je koje će riješiti budućnost. Zasada je sigurno da su pojmovi rata, katastrofičnosti i apokalipse već stekli pravo građanstva u Pojmovniku". Jedan od suradnika na tom projektu, Bogdan Kosanović, u tekstu "Rušitelji zabrana u umjetnosti", isto tako objavljenom u Dnevniku 14. 11. 1990. godine, prenosi sljedeće Flakerove riječi: "Radili smo sistematski i kolegijalno, zazirući od ideologije, tekst nam je bio i ostao estetski kredo. Upravo ta načela držala su nas na okupu". Međutim, ako se avangardizam doista može promatrati kao pravac koji se nalazi na jednom kraju povijesne linije na čijem se drugom kraju nalazi totalitarizam, postavlja se pitanje koliko je u praksi konkretnog istraživačkog procesa bilo doista moguće do te mjere odijeliti avangardnu književnost kao umjetničku praksu za koju je estetski otpor konstitutivan od političkog otpora i zašto je ta potreba za razgraničenjem uopće postojala. Posebice je to zanimljivo u kontekstu činjenice da je sam pojam avangarde u to vrijeme, kako navodi takoder Flaker, pobudivao otpore. Dakle, on se u tom dugom citatu osvrće na to da je bila riječ o nekom tipu proskribiranog pojma i kasnije navodi da je u svijetu pojam avangarde u međuvremenu doživio već i neku vrstu inflacije. To, kako piše 1992, "junačko vrijeme rada na ruskoj avangardi ostalo je za nama. Pojam se danas širi svijetom do neprepoznatljivosti, a etiketa avangarde postaje čak jamstvom komercijalnog uspjeha”. Ne postavlja se samo pitanje političnosti određene književno-umjetničke prakse, nego i pitanje ne uključuje li i samo bavljenje avangardom određenu političnost same istraživačke pozicije. Može li književno djelo ostati estetskom činjenicom i kada je otvoreno ili skriveno politično i može li istraživač, zauzevši političnu poziciju, promatrati objekt istraživanja u estetskoj autonomnosti? Ta pitanja, čini se, samo naizgled 
djeluju naivno, premda su puno puta postavljana. To su pitanja na koja, čini mi se, još nismo dali odgovor... I kada neki tekst prestaje omogućavati političku participaciju ako je avangarda postala jamstvo komercijalnog uspjeha?

Istaknula bih u tom kontekstu da je svijest o složenosti međuodnosa ideologije i književnosti u proučavanju ruske avangarde postojala i među pojmovničarima, o čemu svjedoče gotovo svi primjeri u Pojmovniku ruske avangarde. S jedne strane često se koristi Jakobsonov pojam literarnosti i pojam očuđenja Šklovskog, koji su ciljali promatrati književno stvaralaštvo upravo u autonomnosti. Znamo da je kod Jakobsona poezija jezik u njegovoj estetskoj funkciji. S druge strane, kao što sam ranije rekla, prvi je susret održan upravo s nakanom obilježavanja 60. godišnjice Oktobarske revolucije. I u samoj knjizi Ruska avangarda, objavljenoj 1984, Flaker, polazeći od teze da povijest književnosti mora biti poviješću književnih tekstova u njihovom uzajamnom suodnošenju i dijalektičkom smjenjivanju, navodi da je avangarda povijesno nastalo stilsko zajedništvo književnih tekstova koji nastaju unutar razdoblja omeđenog ruskom revolucijom 1905, velikim prijelomom 1929. i 1932. godinom, gdje je središnji datum upravo dan Oktobarske revolucije 1917. godine. S tim je povezano i iz današnje perspektive nesumnjivo uto142 pističko promatranje uloge književnosti u društvu. Temeljna i dominantna funkcija avangardističkog estetskog prevrednovanja u biti je polazište za prevrednovanje cijelog sustava moralnih, etičkih i društvenih odnosa, cijelog načina života, ali ne s pozicije unaprijed određenog i zadanog ideala, nego u ime optimalne projekcije. Ovdje moram naglasiti da kada se govori o optimalnoj projekciji, tada se ne misli nužno na Oktobarsku revoluciju ni socijalnu revoluciju, nego se misli na neku općenitu ideju budućnosti, koja se može, ali i ne mora poklopiti sa socijalnom revolucijom. Mislim da je ta svjetonazorska tendencija avangardne književnosti evidentna svima koji su čitali neka djela avangardističkih pisaca pisana nakon Oktobarske revolucije, kada oni počinju kritizirati cijeli revolucionarni projekt.

U kontekstu teme ovog izlaganja i postavljenih problemskih osi u ovom ću se dijelu samo kratko osvrnuti na to kako su Pojmovnik i pojmovničari revoluciju tretirali na početku, a kako na kraju, dakle u tom desetom, neobjavljenom Pojmovniku. Svjesna sam da bi prikaz odnosa između estetskog i političkog iz perspektive svih pojmovnika bio puno reljefniji - no svjesno ću ponuditi samo nacrt od kojeg u svojim istraživanjima možete krenuti dalje. U nultom Pojmovniku tema odnosa između avangarde i revolucionarnosti jedno je od središnjih pitanja. Dva su pola uglavnom istaknuta. S jedne strane vrlo smjele tvrdnje, primjerice, mađarskog istraživača Szábolcsija nakon što je onemogućeno bavljenje ruskom avangardom u bivšoj Čehoslovačkoj. On 
u svom prilogu tvrdi da "o istinitoj avangardi možemo govoriti samo onda kada se ona podudara s političkom revolucijom, kada je prati ili priprema. Zaoštreno i s namjernom paradoksalnošću ja bih također mogao reći da sama po sebi avangarda nije revolucija, čak ni revolucionarni pokret; takvom ona postaje tek onda kada se preklopi s revolucijskim valom. Još više zaoštravajući, može se reći da avangarda bez revolucije ostaje pseudoavangardom, pojedinačna pojava”. Tu tezu on oprimjeruje specifičnostima mađarskog konstruktivizma kao tipa avangarde bez revolucije, odnosno pseudoavangarde. Drugi je važan autor u tom kontekstu Hans Günther, koji govori o laboratorijskoj fazi, umjetnosti u revoluciji, i krajnjoj fazi - sjedinjenju umjetnosti sa životom. I on se pita kako je došlo do prijelaza između te prve faze, laboratorijske, do druge, do revolucije u umjetnosti. I on to promatra iz perspektive poimanja umjetničkog znaka, a ta perspektiva mu omogućuje, po mom mišljenju, jedan dosta zanimljiv i važan uvid, naime da je revolucija odigrala značajnu ulogu na koju je umjetnost reagirala svojom pragmatizacijom. U tom je smislu zanimljivo i istraživanje Fritza Mieraua, njemačkog slavista i rusista, koji piše o Majakovskom, odnosno njegovu "Pismu o futurizmu". Majakovskij je to pismo pisao 1922. godine i on tu nalazi "tragove sraza ruske umjetničke avangarde i Oktobarske revolucije. Avangarda je analitičku elementarizaciju vizualnog i poetičkog materijala dotjerala do vrhunske virtuoznosti kad je socijalistička revolucija u toj od 80 do 90 posto nepismenoj zemlji zahtijevala opismenjavanje kao kulturno revolucionarnu akciju". Ti primjeri ilustriraju jedan pol razmišljanja u nultom Pojmovniku. S druge se strane zastupa teza po kojoj su avangardne tendencije postojale i puno prije same povijesne avangarde, primjerice u romantizmu, zbog čega nije opravdano vezivati avangardu uz konkretnu književnopovijesnu situaciju. Na toj se istraživačkoj osi ističe da se propitivanjem utjecaja revolucije uz slamanje autonomije umjetnosti treba baviti sociologija književnosti, a ne književna teorija, povijest književnosti u užem smislu.

Deseti Pojmovnik odnosi se prema ruskoj avangardi, a u kontekstu dinamike odnosa prema revoluciji, na posve suprotan način - revolucije tu gotovo i nema. Dakle, revolucija se gotovo uopće ne spominje kao u bilo kojem smislu konstitutivni aspekt avangardne poetike. Ranije sam spomenula Hansa Günthera, koji piše tekst "Očuđenje", pa govori o jednoj u dosadašnjim istraživanjima uvriježenoj liniji proučavanja očuđenja koju naziva avangardno-formalnom, odnosno aristotelovskom linijom i koju oprimjeruju autori kao primjerice Kandinskij ili Šklovskij, dok drugu liniju naziva platonovskom i vezuje ju uz kritičku spoznajnu tradiciju koja je postojala prije avangarde i koju su primjenjivali primjerice Schopenhauer, 
Tolstoj, Voronskij i tako dalje. Slična argumentacijsko-metodološka logika koja rusku avangardu promatra upravo u dijakronijskom nizu, dakle kroz utjecaje koje je izvršila na kasnije pravce ili kroz utjecaje koje su na nju izvršili raniji pravci, obilježuje druga istraživanja. Općenito bi se moglo reći da u tom posljednjem neobjavljenom Pojmovniku, u radovima posvećenima ruskoj avangardi u užem smislu dominira problem korelativnosti, odnosno mogućnosti njezine kontekstualizacije u širi književnopovijesni kontekst, pa se istraživači često bave nekim pravcima koji se nalaze na tangentama avangarde. Recimo, Jaccard piše o činarima, istraživačica Tamara Levaja piše o Alfredu Šnitkeu koji je rođen 1934, dakle već daleko nakon kraja same avangarde. Spomenula sam na početku Igora Smirnova i Aagea Hansen-Lövea, njima ću i završiti zbog toga što su njihovi tekstovi u tom Pojmovniku, čini mi se, simptomatični za odnos toga desetog zbornika prema avangardi. Tekst Igora Smirnova jedan je od nekoliko tekstova koji se bave onim što bismo, uvjetno govoreći, mogli nazvati klasičnom, odnosno povijesnom avangardom, dakle ne tangentama ili nekim drugim aspektima. Njegov prilog počinje sljedećim riječima: "Pojedine pojave u kulturi rane avangarde u znanstvenoj su literaturi već bile prepoznate kao sadističke po 144 svojem psihičkom ustroju ili pak kao bliske sadizmu”. Prilog se bavi analizom sadističkog sindroma kao zajedničkog nazivnika za najrazličitije manifestacije povijesne avangarde. "Onoliko koliko se povijesnoj avangardi priznaje svojstvo sustava, u njenim tvorcima treba vidjeti pripadnost istom psihotipu". Tekst je naslovljen "Psihoanaliza i avangarda". Drugi tekst, Hansen-Lövea, govori o akmeizmu kao sintetskom tipu avangarde i teze se potkrepljuju izjavom Osipa Mandel'štama, ruskog pjesnika, po kojoj najrevolucionarniji tip umjetnosti nisu futurizam, suprematizam i analitički, začudni tip avangarde nego upravo suprotno, klasična poezija. Hansen-Löve navodi: "na taj način, predodžba o kulturnoj revoluciji, koja je imanentna modernizmu i avangardizmu, pretvara se u svoju vlastitu suprotnost. Estetika začudnosti i inovacije preokreće se, postavlja se s nogu na glavu". Hansen-Löve čak govori o porazu futurizma zbog toga što je bio previše hermetičan, govori o omalovažavanju čitatelja, odnosno o odsutnosti subesjednika u svome tekstu.

Da zaključim, u dvije rečenice, nesumnjivo je da su pojmovničari tijekom deset godina susreta kanonizirali avangardu kao predmet proučavanja i prikazali je u različitosti i intrigantnosti koju ona i u književnopovijesnom i u teorijskom smislu može nuditi. Međutim, iščitavanje Pojmovnika u cijelosti i iz perspektive desetog Pojmovnika omogućuje, čini mi se, jedan značajan uvid: proces kanoniziranja avangarde postupno je poništavao začudni efekt njezinih novotarija. Stječe se dojam da je na kraju 80 -ih i početkom 90 -ih 
avangardu samu trebalo izvući iz, da prizovem Šklovskog, automatizma znanstvenoistraživačke percepcije. I ako je u nultom broju Pojmovnik promatrao avangardu kao umjetnički pokret čija je snaga bila upravo u tome da upozori na anomalije u okruženju i estetskim ih sredstvima učini vidljivima, u desetom je avangarda kao predmet istraživanja sama postala anomalijom. To je nalik upravo onima na koje je upozoravala i koje je činila vidljivima. Nju odlikuje, da citiram Smirnova, sadistički sindrom, ili da citiram Hansen-Lövea, doživjela je poraz zbog svoje hermetičnosti. Drugo, avangarda se nadaje kao pravac koji je potrebno analizirati ne u umjetničkoj samosvijesti i autonomiji, kao što je predloženo na početku, nego upravo suprotno, kroz korelaciju s drugim umjetničkim izrazima i pravcima, kroz neutralizaciju egzotičnosti njezina društveno-kulturnog položaja, što se sve zajedno može interpretirati na različite načine. Možda je to pokušaj da se, unatoč njezinoj kanonizaciji, uvidi da avangarda nije potrošena, o čemu je u svojoj knjizi o Krleži pisao kolega Brebanović. Time bih ja završila, već sam previše vremena, čini mi se, oduzela, hvala vam na pozornosti!

Marina Protrka Štimec: Zahvaljujem na ovom argumentiranom uvidu koji će nam pomoći da našu raspravu proširimo u novim smjerovima. Čuli smo nekoliko poticajnih teza, možda ih možemo povezati s ovim što nam slijedi, prije svega s odnosom teorijskih pristupa avangardi s praksama pisanja unutar i pod utjecajem avangardnih strujanja. Dosad smo čuli nešto više o teorijskim pristupima avangardi ili avangardnim pristupima avangardi. Sad je pred nama dalje tema avangarde i u produkciji, ali i u teorijskom proučavanju na jugoslavenskom prostoru unutar kojeg se avangarda kod nas i proizvodila. O tome će nam nešto više reći kolega Brebanović.

Zvonimir Glavaš: Prije nego što profesor Brebanović krene, jedna napomena: zapisujte si pitanja jer ćemo raspravu otvoriti nakon što završe sva izlaganja.

Predrag Brebanović: Dobar dan svima. Drago mi je što sam ovde. Želeo bih najpre da se zahvalim na pozivu da učestvujem u ovom razgovoru, da dođem i sa vama podelim neke misli o temama kojima se svi bavimo, da pružim nekakav doprinos kao, kako je Marina rekla, gost iz inostranstva mada se ovde ne osećam uopšte gostom, a još manje strancem. Posebno sam vam zahvalan što ste me na otprilike 48 sati izbavili iz one beogradske ludnice u kojoj vlada potpuna histerija povodom izložbe Marine Abramović, umetnice koja je možda nekad bila avangardna, ali više to sigurno nije. 
S tim u vezi hteo bih još nešto reći sasvim lično, nadovezujući se na ovo o čemu je govorila Danijela. Mogu možda to reći čak i u ime sopstvene generacije, mojih kolega koji su počeli svoje studije krajem 80 -ih, početkom 90 -ih godina. Mi smo na izdanjima Zavoda zaista odrasli. Dakle, na Pojmovniku, a da i ne pominjem Biblioteku "L". Recimo, meni prve dve knjige iz Biblioteke "L", mislim, ceo život stoje na radnom stolu - Sukob na književnoj ljevici Stanka Lasića i Priroda kritike Svetozara Petrovića. Sećam se uzbuđenja sa kojim smo kao studenti dočekivali poznije tomove Pojmovnika, šesti, sedmi, osmi... Zaista smo to u realnom vremenu pratili, jer je - kao što je takođe rekla Danijela - Zagreb imao neku vrstu prvenstva u proučavanju avangarde, prevashodno institucionalnog prvenstva. Ovde su stvari, vi to verovatno bolje znate, iz različitih razloga bile institucionalno dobro postavljene, dok je u Beogradu, to je uvek bio moj utisak, stvar i sa avangardom, kao i sa mnogim drugim područjima, uglavnom bila prepuštena pojedincima.

Nažalost, pre otprilike tri godine u Beogradu je umro daleko najbolji poznavalac avangarde, ne samo filmske sa kojom ga ljudi obično povezuju. To je, naravno, Branko Vučićević - pretpostavljam da su mnogi od vas čuli za njega, da su ga čitali, da ga poznaju kao filmskog radnika i pisca o 146 avangardnom filmu. Međutim, on ne samo da nije neko ko je bio uključen u bilo kakve oficijelne projekte istraživanja avangarde nego je delovao potpuno van Akademije. Nikakvog institucionalnog traga njegovo ogromno znanje i spremnost da se to znanje deli nije, na nesreću, ostavilo. Mada je, verovali ili ne, svaka od ovih knjiga koje je pomenula Danijela prošla kroz njegove ruke. Čovek nije ni završio fakultet, a kamoli da je radio na fakultetu, ali sve je to savladao i nama mlađima - kojima su tokom 90 -ih godina pojedine knjige nedostajale, jer tada nije bilo lako doći do nekih izdanja iz Zagreba - oko toga puno pomogao, tako da osećam obavezu da ga u ovom kontekstu pomenem.

Najzad, poslednja lična napomena. Moj takozvani omiljeni živi teoretičar ima običaj da kaže kako svako ko pokušava ozbiljnije da se bavi teorijom ili kritikom, iz razloga komunikacije sa ljudima, sa različitim sredinama, treba da odabere sopstvenu omiljenu šalu posredstvom koje će biti u stanju da premosti neku vrstu komunikacionog jaza - barem u početku razgovora, pa tako i ovog našeg razgovora. Baveći se dosta dugo, bukvalno decenijama, i avangardom, a onda od jednog trenutka naročito intenzivno i ne baš kratko Krležom, shvatio sam da i ja imam svoju omiljenu šalu i da se ona tiče naše današnje teme. Elem, moja šala glasi da u akronimu FNRJ, koji znamo šta znači (to je skraćenica za Federativnu Narodnu Republiku Jugoslaviju), drugo slovo, slovo N, zapravo ne dolazi od reči "narodna", nego od reči 
"nadrealistička”. Ne znam ko je to prvi izgovorio, možda čak neko ko je i trenutno ovde sa nama, ali mi se ta misao uvek jako dopadala i iz nje sam u različitim periodima izvlačio različite ideje o onome čime se bavim. Mogao bi se sigurno napisati tekst o tome, nesumnjivo i čitava knjiga pod tim naslovom, pa bi onda i svaka od tih reči i njihova interakcija detaljno bile objašnjene. Po mom mišljenju, to bi i trebalo uraditi.

Međutim, nama je danas, u sklopu ovog razgovora, najvažnije to drugo slovo, tačnije druga reč. Uzgred, u onoj knjizi koju je Danijela priredila (Kulturna povijest Oktobarske revolucije: sto godina poslije) postoji čitav tekst, ako se ne varam, o skraćenicama, postoji i njihova klasifikacija - na inicijalne, grafemske... To je više nego tipičan primer, da se i tako može govoriti o mom pojmu. Dakle, moguće je u povodu tog pojma govoriti i o Jugoslaviji i o raznim drugim temama, ali je za raspravu o avangardi najvažnije drugo slovo, druga reč. Zašto? Zato što ste, kada izgovorite "Federativna Nadrealistička Republika Jugoslavija", vi faktički već dali odgovor na najvažnije pitanje, pogotovo u prvoj fazi istraživanja avangarde, a to je pitanje avangarde kao formacije, pitanje avangarde kao trajanja. Naprosto, ključno je pitanje u početnoj etapi teorijskog proučavanja avangarde vazda bilo pitanje da li avangardu kao pojam treba razumeti istorijsko-tipološki ili stilsko-tipološki. To je ona problematika o kojoj se govori u drugoj od prve dve knjige Biblioteke "L", u Prirodi kritike Svetozara Petrovića, ne, doduše, na primeru avangarde, nego na primeru nekih drugih pojmova.

Poenta je u sledećem: hoćemo li o avangardi misliti isključivo u istorijsko-tipološkom ili i u stilsko-tipološkom smislu? Ukoliko o avangardi govorimo kao o istorijsko-tipološkoj kategoriji, onda se svodimo na takozvanu istorijsku avangardu, uglavnom se usredsređujemo na period od 1910. do 1935. Počinjemo orijentaciono s futurizmom, završavamo orijentaciono $\mathrm{s}$ uspostavljanjem politike Narodnog fronta i ostajemo u tom vremenski vrlo precizno definisanom domenu. Ukoliko ne želimo tako da razgovaramo o avangardi, ukoliko avangardu obrađujemo kao stilsko-tipološku kategoriju, onda praktično ne postoje nikakve granice, usled čega avangardu doživljavamo kao nekakvu mogućnost koja se može realizovati u bilo kom dobu - ne samo u onom koje je obuhvaćeno istorijskom avangardom, ne čak ni u periodu na koji se obično odnose polemike o avangardi (jer se one često prećutno preliju sa tog perioda u kojem se pojavljuju istorijske avangarde na period, uslovno rečeno, od Lautréamonta do Josipa Severa), nego hipotetički taj vremenski raspon možemo proširiti još više. Na kraju krajeva, znamo da pojam avangarde kao takav uvodi Machiavelli, što znači da potencijalno računamo s mnogo dužom istorijom. $\mathrm{U}$ iskušenju smo, onda, da zaoštrimo 
stvari: da o avangardi govorimo u vremenskom rasponu od pretpismenosti do nekog apokaliptičkog trenutka u budućnosti koji ni mi nećemo iskusiti.

To je stvarno jako važno pitanje $i$, velim, kad pogledamo istoriju rasprave o avangardi, pa i kod nas, pa i ove porođajne muke Flakerove, mi vidimo da to pitanje stalno lebdi. Mislim da se u Flakerovim radovima oseća jedna vrsta kolebanja, neodlučnosti, nespremnosti da se kaže da li je avangarda istorijsko-tipološka ili stilsko-tipološka kategorija. On se čak dosta dugo nije usuđivao da priča o avangardi ni kao o stilskoj formaciji (što je pojam kojeg je uveo on sam), nego je isticao da je posredi neformativna formacija. Itekako je bila prisutna ta dilema, još uvek u prilično zaoštrenom obliku recimo - 80-ih godina.

S druge strane, već je 80-ih godina kod nas u Beogradu, na Katedri za opštu književnost i teoriju književnosti, postojao kurs, kolegij koji se karakteristično zvao i koji je već tim svojim naslovom sugerisao jasan odgovor na to pitanje. Vodio ga je Aleksandar Ilić, pod nazivom Avangarde 20. veka. Dakle, imali smo u naslovu i množinu i vremensku odrednicu, implicirana je bila ideja da se avangarda uvek i svuda može pojaviti. Međutim, kad pogledate čime se profesor bavio u okviru tog kursa - on je zaista bio usred-

148 sređen isključivo na istorijske avangarde i čitao ih je u poetičkom ključu, s tim da ipak jeste nagovestio ono što se desilo posle 1989, uspostavljanjem obrasca kritike avangarde s liberalnih političkih pozicija, kao komponente u totalitarnim političkim projektima.

U samoj teoriji, na svetskom nivou, opisana opozicija i ta vrsta ogromnog raspona u onome šta različiti ljudi pod pojmom podrazumevaju takođe postoji. Tokom 60 -ih, 70-ih, 80-ih godina, ja bih rekao da se čitava rasprava o avangardi može locirati upravo u tu tačku, u to pitanje: istorija ili stil? Ako uzmemo dve možda najuticajnije teorije avangarde iz ovog perioda - jednu je izneo Renato Poggioli, drugu Peter Bürger - to su ta dva pola. Poggioli ima svoju ideju da je avangarda uvek moguća, da se ona stalno pojavljuje, nestaje, umire mlada, ali je večna jer će se stalno pojavljivati. Nasuprot tome, Bürger bi bio tipičan predstavnik istorijsko-tipološkog shvatanja. On će reći: prava avangarda je istorijska avangarda, pokušaji da se avangarda kanonizuje su besmisleni, neoavangarda nije avangarda; da biste bili avangardista, vi morate prezirati instituciju umetnosti i sve institucije; pokušaj institucionalizacije avangarde je principijelno kontradiktoran. Veliki je uticaj dugo imalo Bürgerovo shvatanje, ali sama činjenica da mi i dalje raspravljamo o avangardi posežući i zahvatajući u neke vremenske periode koji nisu striktno vezani za taj kratki odsečak pokazuje da je suprotno shvatanje, koje bismo mogli nazvati pođolijevskim, svakako prevladalo. Stoga se podrazumeva da 
će avangarda i nastaviti da traje, pošto to pitanje figurira kao iskušenje za teoriju nakon 1989.

Meni je, naravno, bliže potonje shvatanje. Ono je prikladno i zbog toga što nam se, ako avangardi pristupimo kao stilsko-tipološkoj kategoriji, pruža prilika da uočimo odgovarajuće dijahronijske momente i da kažemo nešto što je, koliko ja znam, prva u tom obliku, možda malo previše kruto, ali kao zaokruženu koncepciju iznela Dubravka Oraić-Tolić, koja je konstatovala da $\mathrm{u}$ istoriji avangarde možemo pratiti proces kretanja od estetike preko politike ka filozofiji. Drugim rečima, da je ono što zovemo istorijskom avangardom estetički projekat, rekli bismo zapravo antiestetički, jer je to pobuna na planu estetike, ali da istorijski gledano 30-ih godina avangarda ulazi u političku fazu i da onda ide dalje ka nekakvoj, uslovno, filozofiji.

Važno pitanje tiče se onoga što se događalo posle pada Berlinskog zida, pa teorijske rasprave u koje sam imao uvid nastavljaju tu analizu. Groys je već spomenut; meni su bile zanimljive teorije Hala Fostera, Inke Arns i ostalih. Svi oni zastupaju ideju o obnovljivosti avangarde i ono što je posebno interesantnosada se vraćamo našoj priči o Federativnoj Nadrealističkoj Republici Jugoslaviji - sve te teorije nakon 1989, u pokušaju da nastave raspravu o avangardi, posebno mesto, vrlo istaknuto mesto, možda ključno mesto, daju jugoslovenskom iskustvu, jugoslovenskoj avangardi u različitim formama. Doduše, najčešće se pozivaju na izvesne vidove slovenačke umetnosti 80 -ih i 90 -ih, ali uopšte nije slučajno da uz, naravno, ruske primere svi ovi autori, upotrebljavajući čitav niz novih pojmova (postavangarda, retroavangarda, retroutopija itd.), poglavito imaju na umu jugoslovenski kontekst. Čak mnogo više nego ljudi sa prostora Jugoslavije. Kao da ti ljudi koji stvari gledaju sa strane, bez obzira na ideološka opredeljenja, bolje vide. A opet, postoji tu mnogo, ja bih rekao, problematičnih stavova. Postoji i jedna dosta čudna, po meni, tendencija - da se uopšte ne razdvajaju socrealizam i mnogobrojni avangardni pravci, nego se tretiraju u paketu. To je, recimo, kod Groysa veoma izraženo. Ali, zanimljivo je da se u svim tim konceptualizacijama Jugoslavija pojavljuje kao važno mesto.

Ovo, naravno, ne treba da nas čudi, jer ako bismo uslovno prihvatili iznetu dijahronijsku shemu, ključni momenat u istoriji avangarde - gledano i na planu pojedinačnih umetničkih karijera - jeste taj prelazak iz umetničke ili estetske faze u političku. To je apsolutno primarno. To je momenat koji se u 20. veku, znamo, desio 30-ih godina - momenat kojeg zagovornici istorijsko-tipološkog shvatanja praktično proglašavaju krajem avangarde - i nije nimalo neobično da se mnoge rasprave $o$ avangardi završavaju tim periodom. Recimo, ako čitate jedinu objavljenu pravu istoriju srpskog nadrealizma, videćete da se ona završava 1932. godine. Čovek bi rekao da stvari tek tada 
počinju, a ta istorija se završava tada. Ovaj prelazak iz estetičke u političku fazu bio je praćen, dakako, onim što se zove sukob na književnoj levici. $\mathrm{Na}$ delu i nije bilo ništa drugo nego taj sukob, koji je izbio oko spornih relacija između umetničke i političke avangarde.

Taj se sukob javlja svuda. Taj se sukob javlja u Americi, na osoben način, naravno, i u Sovjetskom Savezu, pri čemu možemo da kažemo da je on tamo zatomljen. Kad se Majakovskij ubio, kad je Stalin stavio stvari potpuno pod kontrolu, više nije bilo sukoba, i tu je na neki način kraj avangarde. U drugim zemljama stvari teku drugačije. U Francuskoj imamo sukob Aragon - Breton, kao varijaciju na sukob Stalin - Trockij. Kada je Breton 1933. bio isključen iz Komunističke partije, to nije bilo zbog meditacija o automatskom pisanju ili zbog favorizovanja sna kao naročito važnog momenta u životu, nego su razlozi bili duhovno-političke prirode. Nadrealizam se u tom trenutku profiliše kao jedna karakteristična misaona alternativa u svetu koji klizi u ludilo. On je istovremeno i antifašistički i antistaljinistički, i utoliko predstavlja vrlo, vrlo ozbiljnu pojavu. U Češkoj isto imamo dve struje, Nezval i Teige.

Kod nas je pak u čitavoj istoriji Jugoslavije možda najznačajnija intelektualna činjenica bila vezana uz samo postojanje i način na koji se odvijao 150 sukob na književnoj levici. Zahvaljujući osobenim istorijskim okolnostima avangarda je u Jugoslaviji preživela taj sukob, nastavila da traje, dočekala Federativnu Narodnu ili Nadrealističku Republiku Jugoslaviju i rasprostrla se barem negde do kraja te države. Otuda su i bili mogući ti fantastični umetnički opusi - primerice Krležin ili Marka Ristića. Vi kod njih možete videti čitav taj kontinuitet. Kod Krleže od Hrvatske književne laži (to je nekakva estetska pobuna) preko Dijalektickog antibarbarusa (to je u suštini odgovor na pitanje odnosa književnosti i politike) pa do, recimo, enciklopedijske faze ili poslednjih tomova dnevnika. To je ta, ja bih rekao prirodna, evolucija. Isto kao kod Marka Ristića. Prva faza manifesti, roman Bez mere, druga faza opet politička književnost, 50-ih godina originalna vrsta Markovog angažmana, treća faza napokon nekakva filozofska, Svedok ili saučsnik, Svedočanstva pod zvezdama i tako dalje.

Druge zemlje, druge kulture, druge nacionalne istorije nisu imale tu šansu. Ili se sukob odvija na marginama društva, jer u Francuskoj, kao što znamo, nije pobedio komunizam, ili se vrlo rano razrešuje, kao što je to slučaj u Americi, gde se praktično čitava ta avangardistička scena vrlo brzo i bez nekih većih problema, pogotovo bez ljudskih žrtava, distancirala od Komunističke partije SAD-a. U Češkoj stvar traje samo do 1948, jer sa uspostavljanjem staljinističkog režima imate, realno, kraj češke avangarde, odnosno kompromis sa socrealizmom i slično. Sukob u Jugoslaviji se vodio 
kroz dve etape, Danas i Pečat. On se samo privremeno završio pobedom Partije, da bi se onda nakon 1948. ispostavilo da je ta zemlja jedina koja je, na svoj vlastiti način, izvršila radikalan obračun sa staljinističkim tendencijama, možda čak ne toliko u društvu koliko u umetnosti.

Zato nikada ne treba zaboraviti taj savez, tu interakciju koju simbolizuju na jednoj strani Miroslav Krleža, a na drugoj Marko Ristić. Jer, glavno pitanje je bilo zapravo šta će biti sa nadrealizmom. To je iz perspektive Partije bilo pitanje potrebe da se ljudi "desolidarizuju” od Bretona. Jedan krug srpskih nadrealista - mnogo voljeni i hvaljeni Koča Popović ili nesrećni Đorđe Jovanović - u tom je razdoblju bio osetno bliži staljinističkim idejama. Marko Ristić je bio sam i onda mu u prelomnom trenutku stiže politička, i ljudska, i umetnička, i svaka druga podrška od Krleže, koji je u najdramatičnijem momentu zapravo žrtvovao ili doveo u pitanje i svoj ugled u Partiji i svoju ličnu poziciju samo da bi podržao nekoga koga je naposletku Tito bimself proglasio za buržoaskog degenerika bliskog Bretonu, a to je bio Marko Ristić.

U širem smislu sukob na književnoj levici, pogotovo u takozvanim manjim kulturama, manjim zemljama ili, ako hoćete, na ovom centralnoevropskom potezu koji je pominjala Danijela, od Baltika do Mediterana (ili, kako bi Svetozar Petrović kazao, od Trsta do Gdanjska), bio je posebno dramatičan jer na toj nekakvoj, nazovimo je tako, poluperiferiji Evrope modernizacijski procesi imaju naročitu dinamiku. Tu ovi drugi kulturalni modeli, takozvanih velikih kultura, poput francuske ili nemačke, uopšte ne funkcionišu. Tu nemate onu vrstu kulturne tradicije kakva je francuska, nemate onu vrstu insistiranja na nacionalnom duhu kakva postoji u Nemačkoj. Te centralnoevropske avangarde sa posebnom snagom - i zato i ima toliko teoretičara avangarde u Srednjoj Evropi - odbijaju oba dotadašnja modela (i onaj, uslovno rečeno, tradicionalno-umetnički i s druge strane ovaj nacionalnotvorni) modernizacije i biraju nekakav treći put. Ono što je specifično to je da se taj put u društvenoj, iskustvenoj, istorijskoj praksi realizovao samo u Jugoslaviji i da je blagodareći tome avangarda ostvarila jednu vrstu trajanja kakvu nigde drugde nije ostvarila. Ono što je međutim problem jeste to da u akademskom proučavanju, u našim razmišljanjima, od 80-ih godina pa sve do danas, ta činjenica nikada nije dovoljno valorizovana, odnosno da u institucionalnom smislu ta okolnost kao da nikada nije bilo dovoljno osvešćena. Naposletku, i sam Flaker se stalno dvoumio oko Krležinog statusa. Kad pogledate kako je avangarda počela da ulazi u kanon - pošto je ovde jedno od pitanja koja smo imali bilo vezano za ono što se dešava kad avangarda uđe u kanon i u obrazovanje - uočićete da se u 80-im godinama to sa njom dešavalo na manje-više tragikomične načine. 
Naime, pri ulasku avangarde u kanon u prvi mah su najveći dobitnici bili čovek i pokret koji su možda i najmanje interesantni, a to su Micić i Zenit. Zenitizam je ljudima tokom 80 -ih godina delovao dosta važno. Zašto? Zato što zenitizam nije ni ušao u političku fazu. Dakle, on je ta istorijska avangarda. Micić, šta god mislili o njemu, bio je u političkom smislu neka vrsta idiota koji je u desetak brojeva Zenita promenio sva moguća stanovišta. On počinje kao ekspresionista, pa uvodi dadaizam, pa gleda u Rusiju, pa na kraju dolazi i nekakav tobože balkanski čovek, svašta se tu izmešalo i zato je to možda najmanje inspirativna i najmanje značajna jugoslovenska avangarda, a nekako su se svi odmah uhvatili za nju. Na primer, pre tri godine je u Beogradu održan jedan studentski skup, koji su jako dobro, po mom mišljenju, organizovali zagrebački i beogradski studenti zajedno i koji je bio posvećen jugoslovenskoj umetnosti uopšte. Tada je na jednoj od sekcija koja se ticala avangarde otprilike pet od sedam radova bilo posvećeno Miciću, Zenitu, zenitizmu! Naravno, treba se baviti i njima, ali ne može to biti suština. Suština je negde drugde i rekao bih da vremenom ta istina postaje sve vidljivija i u akademskom proučavanju, na kraju krajeva, zato i mi pričamo ovde o tome.

152 Srećom, u poslednjih desetak godina pojavile su se neke nove tendencije u proučavanju koje idu u ovom pravcu koji je meni najinteresantniji. Pre svega imali smo jedan jako dobar skup o Krleži u Leksikografskom zavodu koji je organizovao Tomislav Brlek, i to u sklopu nečega što se u Beogradu zvalo Festival jednog pisca. Pa smo imali dva skupa o Ujeviću - opet vrlo zanimljivo. Sad imamo ovaj vaš ("Književne revolucije"), a postoji još jedan bilateralni projekat na kojem se nadam da ćete i vi ovde okupljeni gostovati, na kojem ja sudelujem. Tako da se stvari u tom pogledu pomeraju. Dešava se nešto za šta se od početka Vučićević zalagao - on je to zvao "prosejavanjem" avangarde. Ukratko, neophodno je pročistiti građu i prepoznati ono što bi bila najvitalnija supstanca u tom nasleđu.

Mogao bih se onda za kraj vratiti onom svom omiljenom teoretičaru koji je jednom rekao da, po svemu sudeći, živimo u vremenu kada se potvrđuje jedna od onih interpretacija duhovne i političke istorije koju je dao Emerson, po kome se u Americi stalno sukobljavaju dve struje - on to zove "partija pamćenja" i "partija nade". Pritom je u savremenom svetu i samo pamćenje kao takvo postalo ugroženo, a pogotovo njegova institucionalizacija, što međutim ne znači da u pamćenju ne leži neka vrsta, da tako kažemo, spasa. Pamćenje je u osnovi nadanje i zato je neophodno okrenuti se ka prošlosti da bismo onda mogli da vidimo kako biti avangarda danas. Ili kako se avangardom baviti danas. Eto, toliko za ovu priliku. Hvala. 
Marina Protrka Štimec: Hvala puno kolegi Brebanoviću koji je ponudio svojevrsno proširenje teme u odnosu prema prvom izlaganju, kolegice Danijele Lugarić Vukas. Čuli smo evo i sad i ranije rečenicu iz jednog od ovih dvaju neobjavljenih zbornika, rečenicu koja kaže: klasična poezija je najrevolucionarniji tip poezije. S njome se ponovno s nogu vraćamo na glavu. Naime, s obzirom na to da ta rečenica nije dio avangardnog manifesta, nego znanstvenog teksta, mogli bismo razgovarati i o tome koliko je avangarda "zarazna" i koliko bavljenje njome dovodi do ulaska u sferu, u mehanizme kojih inače u uobičajenom discipliniranju struke možda nismo svjesni. Koliko nas naime objektiviranje polja čini objektivnima, odnosno na koji način unutar struke participiramo u mehanizmima nesvjesnog, kreativnosti, izvanjezičnog. Taj se interes prema granicama izgovorljivog možda najbolje može pratiti u pomacima koji su nastajali u poeziji 20. stoljeća. Vratimo li se na to specifično polje proizvodnje unutar hrvatske književnosti, a iz komparativne perspektive, možemo li govoriti o poeziji kao privilegiranom žanru za pristup avangardi? Na redu nam je kolega Oblučar.

Branislav Oblučar: Hvala na pozivu. Ja bih htio dati jednu skicu funkcioniranja pojma avangarde nakon Drugog svjetskog rata u hrvatskoj poeziji s nekim paralelama prema van. Htio bih krenuti iz perspektive povijesnog kontinuiteta, s Flakerom, o kojem smo već čuli, i Danijela je izložila historijat tih savjetovanja koja kreću od 1967. Naveo bih da na početku Poetike osporavanja, jedne od njegovih ključnih knjiga, iz 1983, Flaker konstatira da je u 70-im godinama pojam avangarde stekao pravo građanstva - očito sintagma koja je Flakeru draga - i u našoj sredini, ne samo u akademskim krugovima nego i šire. Sad, iz današnje perspektive to može djelovati malo čudno, mi imamo osjećaj da je pojam avangarde funkcionirao u nekom kontinuitetu, ali kada razgovaramo o povijesnoj avangardi, zapravo vidimo da je pojam tada razmjerno malo korišten. Dakle, avangardni umjetnici su relativno rijetko posezali za tim pojmom, a mnogo češce su afirmirali vlastite $i z m e$, praktički su ih reklamirali u nadmetanju i konkurenciji samih pravaca. Pritom, naravno, bivajući svjesni njihove međusobne povezanosti, kao i vlastite avangardnosti. Sve je to bilo prisutno, ta semantika avangarde, ali nisu imali potrebu za krovnim pojmom, koji se pojavljuje tek povremeno. To se mijenja nakon Drugog svjetskog rata, kada u Europi dolazi do otkrivanja povijesne avangarde, kao i do njezine recepcije, proučavanja i, naravno, ona ima svoje nastavljače među umjetničkim grupama i pravcima koji sada sebe nazivaju avangardama. Dakle, oni se prepoznaju kao avangarda, kao avangardisti, dok ih paralelno njihovi suvremenici proučavatelji 
imenuju i tretiraju kao neoavangardu. Flaker tako tretira neoavangardu kao ponavljanje; on ima tu sintagmu - podgrijana avangarda, nešto što u sebi nije autentično, naprosto je puka repeticija, a original je u povijesnoj avangardi. Na sličan način Peter Bürger iznosi poznatu tezu da je neoavangarda institucionalizirala avangardu. $S$ druge strane, tu su proučavatelji avangarde poput Van den Berga ili Fähndersa, koji avangardu vide kao kontinuitet, koji inzistiraju na upotrebi upravo toga pojma i poslije Drugog svjetskog rata. Oni avangardu sagledavaju organizacijski, kao mrežu, i smatraju da unutar avangarde postoje dva momenta visoke konjunkture, kako oni kažu. Jedan je trenutak intenziteta oko Oktobarske revolucije, a drugi su gibanja oko 1968. Van den Berg predlaže čak i odbacivanje pojma neoavangarde upravo kako bi se naglasio kontinuitet, ali označili i određeni prekidi i premještanja unutar te mreže avangarde, kao i prijenosi, transakcije koje postoje u toj dijakroniji umjetničkog i književnog stvaranja, pa po njegovom mišljenju neoavangarda krivo opisuje i označava taj kontinuitet.

Kad je riječ o recepciji, o naslijeđu povijesne avangarde u hrvatskoj književnosti, bitna su dva momenta: jedan je Flaker i čitava mreža znanstvenika koje je oko sebe okupio te činjenica da se avangarda utvrđuje unutar 154 akademskog polja, što onda rezultira i usustavljenim proučavanjem povijesne avangarde u hrvatskoj književnosti. S druge strane, avangarda je atraktivna i u sferi književnog polja, u samom književnom stvaralaštvu. Tu je zanimljivo vidjeti kako se raspliću te niti koje idu od povijesne avangarde, gdje one izranjaju na površinu i kako se artikuliraju. U tom smislu jako je važan Zvonimir Mrkonjić. Mislim da je njegova knjiga Suvremeno brvatsko pjesništvo iz 1971. ključna za naglašavanje tog kontinuiteta. On prije svega ističe kontinuitet neposredno poslije Drugog svjetskog rata, odnosno 40-e, 50-e i 60-e, i ta knjiga otvara se deklarativnom rečenicom, gotovo avangardističkog naboja, koja kaže: "Jedno se razdoblje hrvatskog pjesništva završilo". Dakle, počinje nešto novo. Onda se postavlja pitanje, ako je tu kraj, traži se novi početak i on nalazi taj početak u nekim pojavama koje su nama danas važne, koje zahvaljujući njemu tada doživljavaju recepciju. To su neki marginalizirani ili zatomljeni, cenzurirani glasovi. Tu su imena poput Radovana Ivšića, kojega je on na neki način rehabilitirao, tamo 70-ih godina, onda Josip Stošić, koji je 1951. bio cenzuriran i zaplijenjena je cijela naklada njegove zbirke pjesama Đerdan, gdje on uvodi jedan tip jezičnog eksperimenta koji se može razumjeti na pozadini konkretizma, također aktualnog nakon Drugog svjetskog rata. Oni su marginalizirani u tom periodu dominiranja socrealističke kulturne paradigme. Tu je i Boro Pavlović, koji sa svojim ludizmom ostaje na margini krugovaške generacije, i tako dalje. Njih Mrkonjić prepoznaje kao preteče 
jednog novog pristupa pisanju poezije koji on imenuje iskustvom jezika. I tu se događa artikulacija jezičnog obrata, koji će onda ostaviti itekako jak trag u pjesništvu 70-ih i 80-ih, tako da zahvaljujući tome avangarda ostaje relevantna. Iako, zanimljivo, Mrkonjić u svojoj knjizi ne spominje pojam avangarde, nego spominje modernizam, radije poseže za tim pojmom, govori o radikalnom ili eksperimentalnom modernizmu, vrlo je blizu semantici avangarde, ali ipak ne koristi taj pojam.

Sad, htio bih se usmjeriti na neke konkretne slučajeve, gdje se avangarda pojavljuje ili artikulira na specifičan način. Prvi je Radovan Ivšić, a drugi Josip Sever, kojega Mrkonjić također ističe, ali mu daje manje prostora. Sever je kasnije doživio mnogo snažniju recepciju nego što se može procijeniti iz Mrkonjićeva čitanja. Ivšićeva je pozicija vrlo specifična. On djeluje na zalaznici avangarde, kako to naziva Flaker. Svoje najvažnije tekstove - to su poema Narcis i drama Kralj Gordogan - piše pod utjecajem francuskog i srpskog nadrealizma. O tome je puno pisao i govorio u člancima i intervjuima nakon 70-ih, kada je opet prisutan u Hrvatskoj. On se 50-ih po odlasku u Pariz susreće s Benjaminom Péretom, uspostavlja kontakt s Bretonom, a oni prihvaćaju njegove tekstove kao nadrealističke. Dakle, kroz njegovo stvaralaštvo i kroz njegovu eksplicitnu poetiku nadrealizam još uvijek živi, prisutnost nadrealizma je itekako aktualna. To se može vidjeti po njegovim stavovima koje dosljedno iznosi, a koji su podudarni s osnovnim postulatima iz Bretonovih manifesta i drugih tekstova, primjerice stav da nadrealizam nije literatura, on na tome cijelo vrijeme inzistira, ili da nadrealizam nije književni stil, nego je to prakticiranje poezije koje mora biti dio životne prakse, koja se napaja pojmovima slobode, traganja za čudesnim, vrednovanjem snova i tako dalje, što je dio nadrealističkog misaonog sustava. Utopijska ili optimalna projekcija nadrealizma postoji kao dio Ivšićeve eksplicitne poetike.

Kada gledamo njegovo pjesničko stvaralaštvo, nipošto se ne može reći da je on bio epigon nadrealizma. Može se, štoviše, ustvrditi da nije toliko slijedio slovo nadrealizma, njihovu ideju smjelih metafora, koliko je slijedio njihov duh, jer njegove intervencije u pjesnički jezik vrlo su suptilne i svakako nešto što je avangardno u odnosu na hrvatski pjesnički korpus u tom trenutku, a i kasnije. Kada je riječ o njegovoj pjesničkoj invenciji, naročito je interesantna poema Narcis, koju on zamišlja kao korsku recitaciju gdje bi glas individue trebao naći odjek u glasu kolektiva, kora koji u tom trenutku čini njegova Družina mladih. "Jeka" je pojam koji je njemu važan za odnos između individue i kolektiva, a paradoksalno je to da njegovo stvaralaštvo tijekom i neposredno poslije Drugog svjetskog rata ostaje bez odjeka. Znamo da je Narcis zaplijenjen 1942. od ustaških vlasti, ali ni nakon 1945. njegova 
Družina ne prolazi puno bolje. $U$ jednom trenutku njoj je vlast zabranila nastupanje i to rezultira njegovim odlaskom u Francusku, pa čak i jednim simboličnim brisanjem, kada je bio isključen iz Društva književnika Hrvatske.

$\mathrm{U}$ tom svjetlu zanimljivo je vidjeti njegov stav kada na jednome mjestu govori baš o pojmu avangarde te kaže da je sumnjičav prema tome pojmu, pogotovo u kontekstu teatra i poezije, zato što za njega avangarda ima vojničke konotacije, ona je za njega naprosto ždanovizam. Tu vidimo stari prijepor između političke i umjetničke avangarde, kao i njegovo distanciranje od onoga što smatra političkom avangardom, on, uostalom, i vidi avangardu kao nešto eminentno političko, premda se to opet može relativizirati kada govori o nadrealističkom pokretu kao avangardističkom. Skepsa spram te političke avangarde može se, naravno, povezati s njegovim ogorčenjem zbog cenzure, ali is Markom Ristićem, na kojega se neprestano vraća. Frustriran je naime činjenicom da je njegov omiljeni nadrealist, od kojega je učio i koji ga je fascinirao, u jednom trenutku postao zastupnik političkog sustava koji ga je ušutkao. Tako da kod Ivšića cijelo vrijeme traje polemika s jedne strane s Ristićem, a s druge strane s Krležom. On Krležu nikada nije posebno cijenio, pa mu on nije bio toliko trn u oku koliko Ristić, kojega optužuje da 156 se ideološki i svjetonazorski potpuno zaokrenuo.

Druga figura nakon Ivšića koja na poseban način reinterpretira avangardu je Josip Sever. Njegova je pozicija drugačija od Ivšićeve. On avangardu prepoznaje kao tradiciju, kao historijski fenomen, ali istovremeno i kao nešto živo, o tome govori njegov susret s Kručënihom, o čemu sastavlja svoj poetski dnevnik. Majakovskij i Kručënih kod njega imaju posebno mjesto, što u njegovom stvaralaštvu rezultira postupcima kojima nastoji reaktivirati neke ključne postupke ruskoga futurizma. Poznata su ta opća mjesta Severove recepcije, da zvuk diktira smisao, nadovezivanje na ideju zauma, civilizacijski nomadizam i tako dalje. Ono što mi se čini važno za Severovo razumijevanje i prihvaćanje avangarde istaknuo je kolega Lujo Parežanin koji je pristupio Severu iz pomalo iskošene perspektive, istaknuvši važnost njegovih prigodničarskih pjesama kojih je većina objavljena u zbirci Borealni konj koju je priredila Dubravka Oraić-Tolić. To su pjesme koje je Sever napisao povodom Prvog maja i povodom obljetnice Oktobarske revolucije koju je tijekom 70-ih proslavljalo Oko, časopis koji je te Severove pjesme pozicionirao na naslovnici, a u kojima on izriče privrženost idealima Oktobarske revolucije. Za razliku od dominantnog čitanja Severa kao postutopijskog pjesnika Parežanin je uputio na jedan tip potpuno drugačije recepcije, gdje Sever reaktualizira utopijske vrijednosti Oktobarske revolucije te eksplicitno navodi svoju pjesničku tradiciju, sve važne figure ruskoga futurizma, u tim 
pjesmama koje se mogu čitati i kao poetski manifesti i, naravno, inzistira i na kontinuitetu spram hrvatske avangarde. Tu su Krleža i Cesarec eksplicitno prisutni, a implicitno Kranjčević i Ujević. Dakle, kod Severa možemo prepoznati nešto drugo od dekonstrukcije utopijskog supstrata, kako je to rekla Dubravka Oraić-Tolić, ako uzmemo u obzir te marginalizirane pjesme, gdje on priziva revolucionarnu i političku tradiciju i ističe sintezu političke i umjetničke avangarde koja je za njega važna i smatra da je upravo ta prevratnička tradicija nešto što treba održati živim.

Nakon Ivšića i Severa, koji svaki na svoj način posjeduju povjerenje u revolucionarni naboj avangarde, 70-ih i 80-ih godina javljaju se pjesnici koji su ponajprije u Severu prepoznali svoj uzor, oni objavljuju u časopisu Pitanja, kasnije i u časopisu Off, i na avangardističkom se tragu okreću ispitivanju jezika kao medija. To je praćeno i jakom teorijskom refleksijom, koja se može vezati za poziciju teoretičara okupljenih oko časopisa Tel Quel, dakle tu imamo izvor poststrukturalizma čiji teorijski koncepti služe kao temelj za refleksiju pjesničke prakse. I tu se etablira niz pojmova koji postaju dio kritičarskog i akademskog žargona i počinju se koristiti upravo u to vrijeme. To su općepoznati pojmovi poput proizvodnje, prakse, materijalnosti označitelja, pisanja, logocentrizma, traga, razlike i tako dalje, marksističko-dekonstrukcijski vokabular koji je usvojio Mrkonjić, ali i drugi kritičari. Pjesnici su pritom ujedno i kritičari, tako da pjesničku praksu prati refleksija o njoj, prisutno je poimanje pjesničkoga jezika kao nečega što je materijalno, pjesma se tretira u smislu artefakta koji ne želi prikriti tragove svoje proizvedenosti, što se može prispodobiti Bürgerovim tezama o avangardnom djelu. Mrkonjić u poeziji jezičnoga iskustva, kako je naziva, prepoznaje $s$ jedne strane odbacivanje tradicije lirskoga intimizma, jer pjesnički jezik nije izraz emocije, a s druge strane u tom jezičnom eksperimentu nalazi implicitnu kritiku ideologije. Na djelu je teza da ideologija nastoji prikriti materijalnost jezičnoga znaka, a time i vlastitu uvjetovanost, odnosno relativnost. U tom kontekstu zanimljiva je činjenica da je osnovna meta telkelista ideologija buržoazije, dok za Mrkonjića to nije prepreka da tu istu kritiku prenese i u jedan drugačiji ideološki kontekst i da je primijeni na ono što prepoznaje kao okoštalu socijalističku ideologiju. Mislim da je ta ideološka kritika implicitna kod pjesnika koji nasljeduju pjesnički tekstualizam i koji potpuno napuštaju ideju utopijske projekcije, živu kod Ivšića i Severa.

U 80-ima avangarda je i dalje pojam koji je u opticaju, možda i više nego prije, štoviše, događa se popularizacija avangarde. Kao primjer mogu se navesti pjesnici i kritičari koji su sebe sagledavali i kao svojevrsne avangardiste nakon avangarde, kao što su Branko Maleš i Branko Čegec, i tu imamo pokušaj označavanja jednog načina pisanja koji će se kasnije nazvati postmodernizmom. 
Postmodernizam se sramežljivo pomalja u tome trenutku, još ranih 80-ih. Kritičarima i pjesnicima još uvijek treba pojam avangarde da označe ono što čine. Čegec tu znakovito govori o "presvlačenju avangarde". Oni su svjesni da je avangarda iza njih, da je ona tek jedna od dostupnih tradicija na koje se suvremeni pjesnik može pozvati. Oni to pjesništvo nazivaju sintetičkim pjesništvom, aleksandrijskom situacijom, i onda se tu pojavljuju pojmovi postavangarde ili retroavangarde, što će kasnije biti zamijenjeno pojmom postmodernizma. Avangarda je kod njih povlaštena tradicija koja se ogleda prije svega u koncipiranju pjesničkoga teksta, što Maleš opisuje sintagmom semantički konkretizam. Stoga postmodernizam u diskusijama o književnosti i pjesništvu 80-ih nikako ne označava smrt avangarde, što je danas općeprihvaćeni stav, nego funkcionira kao kreativna asimilacija nekih njezinih aspekata. O tom svjedoči i časopis Quorum, koji u drugoj polovici 80-ih donosi pretisak Severovog Diktatora i Đerdana Josipa Stošića kako bi se naglasio kontinuitet radikalnijeg pisanja.

I za kraj bih samo istaknuo to da s krajem okvira bivše države jenjava diskurs o avangardi u našem književnom polju i mislim da je, kad se govori o avangardama nakon Drugog svjetskog rata, skiciranje jedne isključivo nacionalne linije nasljedovanja nedovoljno te da je važno sagledati širi 158 jugoslavenski kontekst te neke vitalne poticaje koji su dolazili iz Slovenije, primjerice slovenska neoavangarda i Tomaž Šalamun, koji je imao vrlo živu recepciju upravo u Hrvatskoj, a s druge strane unutar mape post- i neoavangardi treba uzeti u obzir i vojvođansku avangardu, gdje djeluju i važni mađarski pjesnici i pjesnikinje poput Katalin Ladik, tako da je za buduće proučavanje avangarde nakon Drugog svjetskog rata potrebno uzeti u obzir širi jugoslavenski okvir i postaviti pitanje jugoslavenske avangarde kao jednog povijesnog očišta iz kojeg se na novi način i iz šire perspektive mogu sagledati fenomeni koje sam naveo.

Marina Protrka Štimec: Vraćamo se ponovno na tezu o počecima i krajevima, prekidima i kontinuitetima i mladoj avangardi koja svoju revolucionarnost pokazuje i time što se uvijek iznova vraća. $\mathrm{Na}$ tom tragu možemo ponoviti pitanje koje je postavio profesor Brebanović, pitanje koje može funkcionirati i kao teza, a glasi: u suvremenom pristupu avangardi ključnim postaje ono što se događa nakon 1989. Vidjela sam da je profesorica Jukić znakovito kimnula na tu rečenicu, pa samo možemo čuti nešto i o tome. Dakle, što se događa nakon 1989 ?

Tatjana Jukić: Hvala ti, Marina. Umjesto cjelovita argumenta radije bih uz ovu temu ponudila nekoliko provokacija, ne zato što bih se time 
upisala u avangardu, nego zato što ovako zamišljena tribina ima smisla jedino ako otvori prostor za daljnju diskusiju. Prvo, primijetila bih da je zamisao o avangardi fundamentalno moderna, pri čemu je upitno možemo li poslije 1989. godine govoriti o modernosti ili ubrzano usvajamo zapravo predmoderne aparate i procedure. Drugo, toj bih predmodernosti pokušala doskočiti usporedbom avangarde i antike, uz pretpostavku da modernost možemo omjeriti o antiku točno u onim pozicijama u kojima predmodernost ne možemo. S tim u vezi pozvala bih se na Jean-Pierrea Vernanta, meni možda najdražeg klasičnog filologa, povjesničara i antropologa. Vernant zastupa tezu da već Aristotel nije doista razumio tragediju premda ju je kritički opisao i opremio i za filozofiju i za filologiju, jednako kao što već možda Euripid nije dokraja razumio tragediju, barem ne više onako kako ju je razumio Eshil. Prema Vernantu upravo u jeziku tragedije domišljen je konceptualni aparat bez kojega ne bi bilo moguće zamisliti i izmisliti atensku demokraciju u petome stoljeću; Eshilu je to domišljanje kritično na način na koji Euripidu više ne može biti. Drugim riječima, događaj demokracije u petome stoljeću prije naše ere ne bi bio moguć da mu tragedija nije proizvela odgovarajući konceptualni aparat.

To je argument koji rezonira s modernosti kao primarno političkim projektom: antičkome svijetu izum demokracije bio bi ono što su modernome svijetu revolucije, pri čemu književnost ima ono mjesto u modernosti koje $\mathrm{u}$ antičkome svijetu ima tragedija. Odnosno: revolucije modernosti rade ono što je izum demokracije napravio antičkome svijetu, a književnost za moderne revolucije znači ono što je tragedija značila antičkoj demokraciji. Modernost pritom pretpostavlja dosljedno političku - ne više teološku - mobilizaciju svijeta. Bila bi to i zamisliva linija razdvajanja između modernoga i predmodernoga svijeta: ako moderni svijet ne možemo nego angažirati politički, jednako kao što sebe u tome svijetu ne možemo nego angažirati politički, htjeli mi to ili ne, predmoderni svijet ne možemo nego angažirati teološki. Događaj revolucije predstavlja zapravo sve dosljedniju političku mobilizaciju modernoga svijeta, od 17. stoljeća naovamo. Zato prevrati koje kolokvijalno nazivamo revolucijama ne bi bili revolucije u punome smislu te riječi; pozvala bih se na njemačkoga filozofa Christopha Menkea, koji kaže da su revolucije događaji koji transformiraju samu zamisao o transformaciji. Taj će moment u hrvatskoj književnosti zabilježiti već Antun Gustav Matoš kad primijeti da nisu sve ulične demonstracije ujedno i revolucije.

I kritička teorija u 20. stoljeću mobilizirat će književnost na sličan način, i to kad opisuje samo ishodište modernosti. Također, kritička teorija upozorava na međuovisnost modernosti, revolucije i književnosti. Tako 
Walter Benjamin ili pak Carl Schmitt na njegovu tragu u književnosti detektiraju intelektualnu situaciju presudnu za artikulaciju modernosti. Mogli bismo reći: da bi modernost sama sebe razumjela, prvo joj treba književnost. I Benjamin i Schmitt izdvajaju takozvanu baroknu žalobnu igru kao književni žanr koji najpreciznije artikulira modernost i moment njezine inauguracijske samorefleksije. Obojica, posebno Schmitt, izdvajaju Hamleta kao fundacijski moderni tekst. Schmitt izričito napominje da je Hamlet prva faza Engleske revolucije (u studiji Hamlet ili Hekuba), čime sugerira da Hamlet stoji i u intelektualnom ishodištu političke teorije Johna Lockea ili Thomasa Hobbesa i škotske filozofije u 18. stoljeću. Zanimljivo, i Benjamin i Schmitt apostrofiraju atičku tragediju iz petoga stoljeća prije naše ere kao onu literaturu bez koje ne mogu opisati formativno značenje književnosti za modernost, a onda i za događaj revolucije.

Takva tradicija razmišljanja seže i u 19. stoljeće. Kad Matthew Arnold piše o funkciji kritike u sadašnjem trenutku, u istoimenome eseju iz 1864. godine, počinje razmatranjem odnosa književnosti i revolucije. I Arnold povezuje Englesku revoluciju i Shakespearea te sugerira da je Shakespeare bio Engleskoj revoluciji ono što je Eshil bio grčkoj demokraciji. Ističe pritom 160 da Francuska revolucija nema sličnu književnost; ta anomalija Francuske revolucije u velikoj je mjeri uporište Arnoldova eseja i uporište njegova vrednovanja moderne kritike. Slično vrijedi za evropsko 19. stoljeće, u onoj mjeri u kojoj je Francuska revolucija odredila 19. stoljeće: prema Arnoldu problem modernosti 19. stoljeća moglo bi biti to što je u tome stoljeću izostala revolucionarna književnost.

Zašto je to važno? Ako pogledamo avangardu u 20. stoljeću, ona je povezana sa socijalističkim revolucijama otprilike onako kako je Shakespeare povezan s Engleskom revolucijom, a Eshil s grčkom demokracijom. Otišla bih i korak dalje i rekla da je avangarda na sličan način povezana i s konceptom svjetskoga rata, upravo u 20. stoljeću. Avangarda je intelektualna situacija za socijalističke revolucije u 20. stoljeću i za domišljanje koncepta svjetskoga rata. Postavlja se pitanje možemo li uopće razumjeti revolucije u 20. stoljeću bez avangarde kao njihove intelektualne situacije. Zbog toga bih se kratko vratila Francuskoj revoluciji. Naime, pretpostavka obrazovanja u mojoj generaciji bila je da se socijalistička revolucija ne da razumjeti osim u odnosu prema naslijeđu Francuske revolucije. Prema toj optici socijalistička revolucija bila je konzekventan intelektualni i politički dovršetak Francuske revolucije, njezina konzekventna prorada. Zato se, složimo li se s Arnoldom da Francuska revolucija nije našla mjesto artikulacije primarno u književnosti, postavlja pitanje nije li avangarda način da se zaliječi ta insuficijencija i da 
se proizvede adekvatna književnost za događaj socijalističkih revolucija u 20. stoljeću? Da se proizvede adekvatna umjetnost za događaj socijalističkih revolucija (pritom mislim i na film)?

Umjesto zaključka postavila bih dva pitanja, možda kao smjernice za buduću raspravu. U ishodištu prvoga pitanja jest koncept dvojne revolucije, onako kako ga rabi Eric Hobsbawm, a donekle osporava Jürgen Osterhammel. Prema Hobsbawmu političku povijest 19. stoljeća odredilo je naslijeđe Francuske revolucije u točki dodira s industrijskom revolucijom; dvojna revolucija označava dodir i interakciju Francuske i industrijske revolucije u 19. stoljeću. Naravno, zamisao o dvojnoj revoluciji u 19. stoljeću naslanja se na Marxa i na Marxov filozofski i politički projekt. To bi značilo da projekt socijalističkih revolucija u 20. stoljeću proistječe iz djelokruga dvojne revolucije - iz točke gdje se dodiruju i međusobno korigiraju Francuska revolucija $\mathrm{i}$ industrijska. Moje bi pitanje bilo: ako industrijska revolucija nalazi svoje ishodište u političkoj kulturi koja je inaugurirala modernu revoluciju, a to je Engleska, nije li dvojna revolucija ustvari poziv da socijalističke revolucije u 20. stoljeću, a onda i koncept svjetskoga rata, domislimo ne kao istrajavanje ili proradu Francuske revolucije, nego kao kulminaciju modernosti? (I Schmitt sugerira da industrijska revolucija svoju osobitu konstituciju duguje Engleskoj revoluciji: činjenici da revolucionarna Engleska zamišlja državu i institucije drugačije od kontinentalne Evrope. Na tu osobitost upućuje i Gilles Deleuze u Dijalozima.) Pri čemu kulminacija modernosti označava dosljednu političku mobilizaciju svijeta, bez teoloških preostataka.

Drugo pitanje bilo bi: ako su socijalističke revolucije u 20. stoljeću dovršile političku mobilizaciju svijeta, što se događa poslije 1989. godine i kolapsa socijalizma, kad je moderni projekt, tako postavljen, domišljen do kraja? Što se događa u trenutku kad se time iscrpila avangarda kao intelektualna situacija revolucije? Možda je odgovor na to pitanje sadržan u eseju koji je nedavno objavio Jean-Luc Nancy povodom stote obljetnice Oktobarske revolucije. Esej je to o Leninu i elektrifikaciji, ustvari esej o Leninu i industrijskoj revoluciji. Nancy u njemu postavlja tezu da se moderna misao iscrpila u času kad je Leninova politička zamisao o elektrifikaciji ustupila mjesto teologizaciji tehnologije, pa smo danas skloni pripisivati tehnologijama teološku dimenziju. U posljednjoj rečenici Nancy se pita možemo li danas još zamisliti kako živjeti zajedno, živjeti politički, bez bogova, pa makar ti bogovi bili bogovi tehnologije. Nancy time sugerira da smo danas već pristali na život koji više nije moderan, ili barem više nije dosljedno moderan, jer tehnologiji pripisujemo djelokrug božanske intervencije. Ako to znači da smo pristali na odustajanje od modernosti, to također znači da 
više ne korespondiramo s avangardom - ne zato što to više ne bismo htjeli, nego zato što to više možda ne znamo. Iz čega slijedi da ćemo se prema avangardi i revolucijama, i to u najboljem i najsretnijem slučaju, odnositi onako kako su se prema tragediji odnosili već Euripid, a onda i Aristotel. Eto, time bih završila. Hvala vam.

Zvonimir Glavaš: Usmjeravamo poglede prema vama sada, na vaša pitanja koja ste marljivo popisali ili memorirali za ovo vrijeme. Možete slobodno postaviti pitanje bilo kome od naših današnjih izlagača, samo dignite ruku. Molimo vas još jednom samo da kažete ime i prezime prije pitanja da vas možemo kasnije kontaktirati oko autorizacije. Uputite svoja pitanja ili priloge raspravi...

Moramo mi probiti led? Ja ću onda iskoristiti ovu poziciju i, zapravo, možemo početi od posljednjeg, ispričat ću se ostalim izlagačima, njima ćemo se vratiti. Za profesoricu Jukić možda, kad kažete da Francuska revolucija nema svoje književno djelo na onaj način na koji ste povezali ostala spomenuta djela, svoj književni odraz, svoju književnu artikulaciju, možemo li tome suprotstaviti možda Rancièreovu perspektivu na Francusku revoluciju i na

162 sve oko toga i pitati bi li se moglo kontrirati Rancièreovom tezom da ako ona nema svoje jedno djelo ili jedan svoj književni pokret, da nam je dala literarnost kao uvjet književnosti uopće? Ako pogledamo Rancièreova Imena bistorije recimo, on se tu bavi problemom Francuske revolucije i kaže da ne smijemo dopustiti da ju historija apsorbira, ali ono u čemu on vidi ključ za revoluciju u historiji jest, zapravo, događaj, odnosno fenomen otvaranja brana jeziku, simboličkoj produkciji, simbolizaciji i, zapravo, izmještanju, iščašivanju govora s onih mjesta na kojima je bio, da je to po definiciji govor koji je izmješten s onog mjesta gdje je po pravilima pripadao, da je to govor koji je anakron, koji je u diskrepanciji s vremenom i mjestom kojem pripada, a na neki način ako krenemo i prema formalističkom određivanju, avangardnim određivanjima književnosti, literarnost bi podrazumijevala govor koji je na neki način izmješten iz svog "prirodnog" zakonitog mjesta, koji se tu izmješta, iščašuje. Praktički, ono što vidimo da se tu pojavljuje kao određujuće svojstvo institucije književnosti, koja nastaje u to vrijeme, na neki će način biti referentna točka u kasnijim raspravama o revoluciji, čini mi se.

Tatjana Jukić: Hvala vam na pitanju. Naravno, Francuska revolucija ima svoju književnost, to je neupitno. Jednako kao što 19. stoljeće ima svoju književnost. Ako išta, 19. stoljeće jest stoljeće književnosti, stoljeće romana, stoljeće literarnosti o kakvoj govori Rancière; mogli bismo čak reći da knji- 
ževnost ima svoje stoljeće, a to je devetnaesto. Čak bih postavila tezu da je upravo roman 19. stoljeća aparat za dosljedno domišljanje transatlantskih revolucija (Američke, Francuske ali i industrijske), čime se stvaraju političke i intelektualne pretpostavke za avangardu u 20. stoljeću i za socijalističke revolucije. No, Arnold zapravo ističe da je za Francusku revoluciju filozofija racionalizma odigrala ulogu koju je za Englesku odigrao Shakespeare - da filozofija racionalizma zauzima ono mjesto koje je u Engleskoj revoluciji zauzela književnost. Tako Arnold, primjerice, kaže da Engleska revolucija postavlja pitanje što je zakonito, a Francuska revolucija što je racionalno. Valja također primijetiti da u velikim postrevolucionarnim kulturama u 20. stoljeću nema revolucija, nema ih više zapravo ni u devetnaestome, čak i kad se događaju velika politička previranja i nasilja: revolucije nema u Britaniji, nema je u SAD-u, nema je u Francuskoj, te su kulture odradile svoj revolucionarni posao. Kad pogledate revolucije u 20. stoljeću, one se događaju u kulturama koje nisu postrevolucionarne. Dakle, mogli bismo reći da je 20. stoljeću bilo preostalo da do kraja politički mobilizira svijet, i ta se dosljedna politizacija svijeta može pratiti kroz glavninu 20. stoljeća. Zbog toga treba postaviti pitanje može li se poslije 1989. govoriti o daljnjoj politizaciji svijeta ili je riječ o stanovitoj teologizaciji svijeta, koja se više ne odvija prema obrascima koji su vrijedili u srednjem vijeku, ali se odvija uz pomoć nekih naših odustajanja, koja možemo pratiti sada unatrag desetak godina: sve manju konkurentnost ima koncept univerzalnih ljudskih prava, sve smo skloniji esencijaliziranju i uskim identitetskim politikama. I već je zbog toga neizvjesno možemo li još uvijek procijeniti kako funkcioniraju književnost i umjetnost u ukupnosti modernoga.

Zvonimir Glavaš: Hvala vam. Dalje, pitanja... u odnosu na neko od ranijih izlaganja?

Maša Kolanović: Slušajući sve vas, referirali ste se na Pojmovnik ruske avangarde Aleksandra Flakera. Ovo pitanje može biti praktički postavljeno svima, a možda će se Danijela ipak osjećati nekako pozvanom da odgovori. Vidjeli smo, Pojmovnik ruske avangarde zajedno su uredivali Dubravka Ugrešić i Aleksandar Flaker. Zanima me zapravo uređivačka pozicija Dubravke Ugrešić u Pojmovniku i naslijeđe avangarde ne samo u njezinoj poetici nego i, ja bih rekla, u politici njezine estetike, posebice nakon 1990. godine i povratka, kako bi rekla Tatjana Jukić, u ovo predmoderno vrijeme. Dakle, ja mislim zapravo da je upravo ta avangardistička koncepcija tu odigrala ključnu ulogu u dosljednosti njezinih stavova i njihovoj artikulaciji. Zanima 
me kakva je bila njezina pozicija u ovom uređivačkom segmentu i čini mi se da bi to mjesto trebalo dodatno podcrtati.

Danijela Lugarić Vukas: Jako mi je drago da je Maša to spomenula jer je u mom izlaganju (dijelom i u drugim izlaganjima) nekako ispalo - nenamjerno - da je govor o avangardi govor o Aleksandru Flakeru. U integralnoj je verziji moga izlaganja Dubravka Ugrešić prisutna na puno mjesta - ona je, konačno, bila suurednica Pojmovnika. Zanimljivo je da se iz perspektive književnog stvaralaštva Dubravke Ugrešić ona u jednoj od posljednjih knjiga, romanu Lisica, vraća tim (avangardnim) počecima. Prvu priču u toj knjizi naziva "Priča o tome kako nastaju priče" i razvija je kroz metaforu Borisa Pil'njaka, ruskog pisca kod kojega su revolucionarne promjene značajno utjecale na prirodu njegova estetskog jezika, odnosno na bezsižejnu, eksperimentalnu prozu. Dakle, u tom smislu da, nedvojbeno. Bit će zanimljivo vidjeti u kojem će se smjeru priča o Pojmovniku ruske avangarde razvijati ako se odlučimo na objavljivanje desetog Pojmovnika - pretpostavljam da je ona i taj deseti Pojmovnik uredila. Konačno, za konferenciju posvećenu "Totalitarnoj umjetnosti", za dvanaesti Pojmovnik (odnosno prvi, Zagrebacki

164 pojmovnik kulture) pozivno je pismo slala Dubravka Ugrešić, i to je bilo u travnju 1993. godine. Tako da da, taj projekt nije samo Flakerov unatoč tomu što se na njega svi redovito referiramo, premda to ne znači da avangardu na njega i svodimo. Sam Flaker je, to moram naglasiti, puno puta naglašavao važnost ljudi koji su radili s njim na tom cijelom projektu. Dakle, on sam nikada nije preuzimao zasluge za avangardu. Vidjet ćemo sad, možda, ako priča dobije neki nastavak u objavljivanju desetog Pojmovnika, možda ću nešto konkretnije moći odgovoriti o njezinu današnjem odnosu prema tom svom bavljenju ruskom avangardom.

Marina Protrka Štimec: Dakle, jako je zanimljivo pitanje, hvala Maši što ga je postavila. Ja bih se možda nadovezala na drugi dio pitanja: kako se njezin znanstveni rad odrazio na njezino stvaralaštvo, na njezin društveni, kulturni, možemo reći i politički angažman kasnije. To se sigurno može istražiti detaljnije i vrlo precizno jer je vidljiva veza između avangarde i načina na koji piše svoje prve romane, u određenoj vrsti formalne subverzije npr. koja je značajna i u relaciji koju je kolega Oblučar spomenuo - između avangarde i postmoderne. Kod nje se doista dobro vidi taj aspekt subverzije ili otpora forme koji ima svoju razvojnu liniju koja je, naravno, uvjetovana i drugim aspektima, ali sigurno se može krenuti od hipoteze da je znanstveni rad Dubravke Ugrešić, bavljenje avangardom, utjecao na njezin književni 
tekst i na društveni angažman. Jedna od teza koja se danas mogla čuti jest, što je kolega Oblučar naglasio, da se avangardni autori prije Drugog svjetskog rata vrlo rijetko nazivaju avangardnima, iako svjesno ulaze u tu vrstu pisanja i razumijevanja, da imenovanje dolazi kasnije, možda s nekom vrstom institucionalizacije avangarde kao povijesnog i poetičkog fenomena. Ja bih rekla da se ta praksa može vidjeti kroz pisanje različitih autora koji sebe ne nazivaju avangardnima. To je sad nama neka ideja ili neka hipoteza koju bismo htjeli istražiti iz različitih perspektiva. Uzmimo primjer spomenutog Tina Ujevića koji je pisao puno i o nadrealizmu i o avangardi i koji se družio sa srpskim nadrealistima, koji su ga bili prisvojili kao neku vrstu svoje ikone, pa su mu i posvetili prvi broj svog časopisa Svedočanstva, ali koji o avangardi piše vrlo kritički. Istodobno, pišući kritički o avangardi i avangardnim pokretima, on ispovijeda i demonstrira vlastitu avangardnost. Dakle, on će reći, ja sam prije avangarde napisao to i to, što zapravo pokazuje da se ti mehanizmi avangardnog otpora pisanja ili revolucionarnog zapravo probijaju kroz književnost. Upravo u tome vidimo svoj zadatak i prostor za nova istraživanja: odrediti gdje se avangardni impuls vidi i kod pisaca koji se ne ispovijedaju kao avangardni. $U$ tom smislu je kod Dubravke Ugrešić, a još više kod Irene Vrkljan vidljiv element otpora koji se javlja kroz nešto što bi se vrlo široko moglo nazvati ženskim pisanjem ili ženskim pismom. Zanimljivo je možda da samu etiketu ženskog pisma obje autorice autopoetski niječu. Kod Ugrešić se može prepoznati i kao svijest o otporu kroz pisanje o ženskom identitetu ili kao vrsta otpora koji žensko pisanje u odnosu prema pismu pokazuje i koji je kao takav srodan avangardi. Ovakvim pristupom moguće je istovremeno revidirati koncept ženskog pisma i odrediti nivoe (narativne, značenjske) na kojima se avangardno realizira u pismu Dubravke Ugrešić i nekih drugih autorica.

Danijela Lugarić Vukas: Isto tako jako zanimljivo. Mislim da nije slučajno ono što sam govorila. Dakle, ta jedna linija koja kreće od avangarde, a završava u totalitarnoj umjetnosti, da bi se cijela priča o Pojmovniku završila konferencijom koja se zove "Totalitarna umjetnost", a pritom je Dubravka Ugrešić jedna od prvih i najglasnijih kritičarki upravo totalitarnih sustava. Priča o avangardi je prije svega vrlo složena priča, pa i na osobnoj razini, u kojoj se puno različitih sudbina ispreplelo te je puno unutarnjih i vanjskih faktora na zanimljiv način formiralo cijelu priču i o avangardi i o Pojmovniku, a onda i o sudbini ljudi koji su bili vezani uz rusku avangardu, koji su uz nju rasli ne samo znanstveno nego i osobno, a onda i znanstveno i osobno, to je i s Dubravkom Ugrešić nesumnjivo važan moment. 
Predrag Brebanović: Povod je Dubravka Ugrešić, ali ovo pitanje možemo možda malo proširiti. Kad sam govorio u prvom licu, ispovedno o Pojmovniku, mislio sam na ono uzbuđenje s kojim sam čitao te tekstove, imajući u vidu da ću se možda i sam baviti istom strukom. I moram reći da u vreme kada sam malo više verovao u koncept nauke o književnosti ili znanosti o književnosti - danas u to uopšte ne verujem, naravno - da sam neke od najuzbudljivijih tekstova pročitao upravo u Pojmovniku, i to napisane iz pera, čak isključivo, autorki. Recimo, još uvek se sećam teksta Dubravke Ugrešić o Dobyčinu, koji je sjajan tekst, vrlo dinamičan - on je, pre svega, fenomenalno pisan, on je brz, atraktivan, a zapravo pripada znanstvenom žanru. Sećam se i teksta Žive Benčić o infantilizmu, koji mi je užasno mnogo pomogao u trenutku kad sam pisao o nekakvim sličnim fenomenima. Teksta Dubravke Oraić-Tolić, koji će kasnije ući u njenu knjigu o citatnosti, i tako dalje. Ako smo registrovali da je u nečemu Zagreb imao jednu vrstu prvenstva, onda treba istaći da je artikulacija književnonaučnog stila u Pojmovniku bila vrhunska, a prednjačile su, po meni, upravo autorke. To je zanimljiva perspektiva na taj projekt.

166 Anonimna sudionica: Svjesni smo da se to prešućivanje Dubravke Ugrešić ne može baš psihoanalizom opravdati, već devedesetima, to je možda malo izvan psihoanalize.

Danijela Lugarić Vukas: Ovom sam prilikom samo govorila o svom izlaganju...

Anonimna sudionica: Dobro, ali samo da imate snimljeno, da.

Zvonimir Glavaš: Možete samo ime...

Anonimna sudionica: $\mathrm{Ne}$, htjela bih ostati anonimna.

Zvonimir Glavaš: Dobro. Još neko pitanje možda?

Andrea Milanko: Evo, pitanje, provokacija na provokaciju. Kad smo već kod provokacija, dakle vidimo već kroz razvoj, od početaka avangarde, zapravo, avangarda se oslanja na vrlo rahle definicije kolektiva. Svi ti kolektivi se manje-više brzo raspadnu i ti pravci se međusobno zamjenjuju. Postoje prebjezi, postoje negiranja pripadnosti, zatajivanja pripadnosti. Zanima me oko čega bi se formirala kakva buduća zajednica sinova ako više nema oca? 
Tatjana Jukić: Deleuze kaže, jedina prava opasnost za revolucionarnu zajednicu jest povratak oca u nju. Staljinizam bi bio povratak oca u revolucionarnu zajednicu. Mnogo toga što se zbiva nakon Američkoga građanskog rata jest povratak oca u američku revolucionarnu zajednicu. U postrevolucionarnim društvima nerijetko dolazi do takvoga povratka oca. Primjerice, već Sade kaže - a Deleuze ga citira - da je Francuska revolucija izdala samu sebe kad je počela donositi zakone. Danijela je spomenula opasku Igora Smirnova o sadizmu avangarde, možemo taj sadistički moment tražiti već $\mathrm{u}$ analizama Francuske revolucije. $\mathrm{U}$ tome smislu Deleuzea zanima pokazati da je opreka izmedu revolucionarne vatre i nasilja s jedne strane i dogovora, ugovora i hladnoće s druge strane neadekvatna i disfunkcionalna opreka, jer su oba ta momenta konstitutivna za revolucije; Deleuze upućuje na zakon kao na temeljni problem u revolucionarnoj zajednici. To se možda najbolje vidi u njegovoj studiji Hladno i okrutno. Takoder, postavila bih pitanje je li opreka između modernizma i avangarde - opreka s kojom smo odrastali u intelektualnom krilu Zagrebačke škole - je li ta opreka doista funkcionalna ili bismo taj odnos trebali domisliti drugačije? Što ako su modernizmi postrevolucionarnim književnostima ono što je avangarda revolucionarnim književnostima u 20. stoljeću? Možemo li u tome slučaju govoriti o opreci ili o njezinoj dekonstrukciji? Ne odgovara li relacija modernizma i avangarde relaciji postrevolucionarnih i revolucionarnih kultura u 20. stoljeću? I nije li dekonstrukcija opreke između revolucionarnih i postrevolucionarnih kultura način da razumijemo modernost kao takvu? Uz pretpostavku da danas uopće možemo razumjeti modernost ako nam je, barem u Evropi, dovoljna floskula da smo, nominalno, prevladali totalitarizme. Zbog toga nisam sigurna u kojoj je mjeri evropski politički identitet danas - moderan.

\section{Andrea Milanko: Hvala.}

Zvonimir Glavaš: Ako se mogu samo nastaviti na ovu razmjenu mišljenja... kad kažete da je ipak u središtu, da je nužno nečim održavati vatru, i da je zapravo ključ u ovoj svijesti o dogovornom aspektu svega, čini mi se da tu onda dolazite jako blizu zapravo i Rancièreovim i Derridaovim i Laclauovim kritikama Deleuzea, da nije dosljedan u toj zajednici braće bez oca, odnosno da se ne može misliti zajednica bez oca, bez nekog utemeljujućeg akta, pa makar provizornog. I tu je onda na djelu famozna razlika izmedu Marchartovih termina postfundacionalizma i antifundacionalizma, gdje ta trojka pokušava na neki način pokazati, samo ne tim riječima, da je Deleuze, iako sebe prikazuje kao dosljednog antifundacionalista, ipak postfundacionalist. Na kraju krajeva, 
na tom tragu su i neke moje opaske a propos Deleuzea na drugim mjestima. Čini mi se da ste i vi sada u ovoj replici bliski tom stavu? Ako ne, ispravite me.

Tatjana Jukić: Dopustite mi da se načas opet vratim u 19. stoljeće, ovaj put Tocquevilleu. Kad Tocqueville uzima Ameriku kao demokratsku kulturu koja mu služi da vrednuje francuski revolucionarni projekt, on na prvo mjesto stavlja vrijednost dogovora. Moderna Amerika počinje time što su se engleski doseljenici u Novu Englesku, i prije nego što su stupili na tlo Novoga svijeta, dogovorili o kolektivu koji će izgraditi. Taj dogovor - takva politička praksa - jest u podlozi i glasovite maksime Johna Lockea da je u početku cijeli svijet bio Amerika. To bi značilo da je Tocquevilleu francuska modernost u bitnome transatlantska modernost te da mu je Francuska revolucija u bitnome transatlantska revolucija. Tocquevillea bih uzela kao okvir za vaš komentar o Deleuzeu. Rekla bih da Deleuze privilegira transatlantski moment modernosti; također bih rekla da Derrida, barem donekle, deprivilegira taj transatlantski moment. To se posebno jasno vidi u Derridinu tekstu o Thomasu Jeffersonu iz 1976. godine, u povodu dvjestote godišnjice Američke revolucije. Moglo bi se reći da Derrida konzistentno 168 teologizira Ameriku. Pritom valja upozoriti na činjenicu da dekonstrukcija i poststrukturalizam, najizrazitije možda Derrida, svoju akademsku legitimaciju prvo nalaze u Americi, kao evropski import, a tek onda u Evropi; to znači da se dekonstrukcija u 20. stoljeću ponaša onako kako su se ponašale transatlantske revolucije u osamnaestome. Inače, o transatlantskoj konstituciji poststrukturalizma piše Elizabeth Bruss još početkom 1980-ih u knjizi Prekrasne teorije. Rancière, Badiou, Laclau... svi oni, htjeli-ne htjeli, pišu na tragu te relacije, pa onda i o Deleuzeu. Zanimljivo, i u socijalističkoj Jugoslaviji, ali i u predrevolucionarnoj Jugoslaviji, primijeti se jedan takav moment, konkretno slučaj Koče Popovića. Francuski đak, francuski student filozofije, bilingvalno obrazovan, nadrealist na dva kraja, u Francuskoj i u Srbiji, sudionik u Španjolskom građanskom ratu i onda u socijalističkoj revoluciji u Jugoslaviji u Drugome svjetskom ratu...

Predrag Brebanović: Ali fali mu Goli otok. Tako gledano.

Tatjana Jukić: S obzirom na to koliko je Tito bio skeptičan prema Koči Popoviću, možda mu Goli otok i ne fali u biografiji. S druge strane, valja zaviriti u njegove ratne tekstove, u ratni dnevnik koji je pisao pola na francuskom pola na srpskom; doživljaj ofenzive, na primjer, uspoređuje s čitanjem Edgara Allana Poea, pri čemu lektira Poea više nije dovoljna. Kad 
već govorimo o transatlantskim infleksijama. A opet, upravo je Koča Popović preustrojio partizanske jedinice u armiju, i to po uzoru na Trockoga, jer je Trockij - ne Stalin - ustrojio Crvenu armiju. Trockij, koji je napisao Književnost i revoluciju.

Predrag Brebanović: Pri tom pronalaženju kontinuiteta kod Koče jako je zanimljivo da je ipak bilo nužno preskakati neke momente. Meni je, recimo, za ovu vrstu rasprave najinteresantniji onaj Koča koji piše protiv Dijalektickog antibarbarusa. Ne tvrdim da pri tom nije u pravu. Dakle, to je ona situacija za koju je Krleža rekao da je tada Tito bio u pravu, ali onda je Tito posle 1948. došao na njihove pozicije. Postoji zaista kontinuitet kod Koče, ali postoje i nekakvi viškovi koji mu omogućuju da, recimo, sada bude ikona, uslovno rečeno, liberalne Srbije, da dobije ulicu koja se nekad zvala, nećete verovati, Zagrebačka.

Tatjana Jukić: Nije da Koča nije objavljivao i kod Krleže...

Predrag Brebanović: Ja imam neku tendenciju da ljude smatram odgovornima za ono što se desilo i posle njihove smrti, tako da bih malo korigovao tu sliku o Koči... Možda mi je zato to izletelo, možda na nivou psihoanalize, verovatno sam želeo da je narušim.

Tatjana Jukić: Zgodno. Jer je upravo kod Krleže pisao protiv psihoanalize.

Predrag Brebanović: Ali je doprineo, takođe, afirmaciji psihoanalize u tadašnjoj Jugoslaviji. Da, Koča je zanimljiv, ali je zanimljivo i ono što mi nemamo u tom buđenju interesovanja, recimo, konkretno baš za Koču Popovića. Mi nemamo ništa napisano o njemu što bi bilo suvislo. Niko nije napisao nešto o Kočinom, na primer, delovanju kroz časopise, o njegovim tekstovima. Jednom su samo reizdati ti tekstovi, negde polovinom 80-ih. Mi nemamo poštenu knjigu o Koči Popoviću. To je ono što treba raditi, pa tek onda i Koču uključiti u ovaj naš okvir.

Zvonimir Glavaš: Hvala. Još neko pitanje? Je li se netko ohrabrio u međuvremenu?

Bruno Sokolić: Možda će ovo biti malo naivno pitanje studenta, profesoru Oblučaru, možda više kao piscu ili čitatelju nego kao profesoru. 
Zanima me mogućnost avangarde danas. Spomenuli ste Čegeca i Maleša, koji su bili pomalo subverzivni u svoje vrijeme u Jugoslaviji, međutim danas su skoro, čini mi se, sigurna imena. Izdaju knjigu, dobiju pozitivne reakcije, kritike i tako dalje. I mislim da se to jako osjeti i u svim drugim umjetničkim područjima. Na primjer film ili glazba. Nedavno sam bio na Muzičkom bijenalu u Nacionalnoj sveučilišnoj biblioteci, bio je jedan, recimo, performans, nešto između koncerta i plesa, teško je to opisati [radilo se o djelu The Otheroom Rolfa Wallina]. A kada smo izašli, vidjeli smo da na stepenicama pred NSB-om spava beskućnik. Bili smo u tom jednom potpuno zatvorenom, eksperimentalnom prostoru, prisustvovali jednom potpuno neobičnom događaju, dok je vani svijet išao svojim, posve drugim putem. I to me u biti zanima - imate li osjećaj da bi odnekuda mogao doći nekakav novi poticaj, nekakav veliki umjetnik kakvi su nama danas ideali i vrhovi, Schönberg, Sever, Slamnig, Krleža i tako dalje. Odakle bi to moglo doći, neka avangarda, bilo samo umjetnička bilo i ona koja bi povukla i društvene konzekvence?

Branislav Oblučar: Naravno, predviđati je uvijek nezahvalno, praktički 170 nemoguće. U pravu ste što ste tiče tih autora koje ste spomenuli, koji su baštinili avangardu pa bili čitani i promatrani kao nešto što je subverzivno, a postali su dio kanona. Išto sad? Da li nasljedovati takav stil znači automatski i biti avangarda? Ne bih rekao. Kolega Brebanović u svojoj knjizi o Krleži na jednom mjestu kaže da bi se o avangardi trebalo razgovarati relacijski, da je to relacijski pojam, pojam koji se ne može unaprijed definirati, nego se artikulira u kontekstu. Dakle, u samom kontekstu možemo sagledati, pa čak i retrospektivno, što je avangarda ili što bi avangarda mogla biti. To mi se čini bitno, da se ne može igrati na sigurnu kartu u tome smislu. Ono što mi je zanimljivo kad je riječ o suvremenoj književnosti, što mi je ostalo u pamćenju kao artikulacija veze između književnog čina i političkog odjeka, bilo je gostovanje Édouarda Louisa u Zagrebu, mladog francuskog pisca koji u svojim romanima na grubo realistički način opisuje odrastanje u francuskoj radničkoj klasi, u siromaštvu, što formira njegov seksualni identitet. U svojim nastupima on je vrlo energičan i ti su nastupi vrlo dojmljivi. $U$ jednom trenutku on je rekao da mu nije jasno kako čovjek nakon što pročita njegovu knjigu i nakon što posluša njegov nastup može izaći iz dvorane i ne glasati za francusku ljevicu, koja bi mogla promijeniti društvo. Kao krajnji odjek književne priče on vidi mogućnost društvene promjene, a pritom ukazuje i na mimoilaženja u razumijevanju zato što, naravno, ljudi izlaze iz dvorane i možda neće glasati za ljevicu, njima se naprosto svidio tekst, a on smatra da 
tekst mora imati nekakav politički refleks, i to je po mojem mišljenju blisko avangardističkome duhu.

Zvonimir Glavaš: Još netko, pitanje? Ne? Onda opet ja. Pitanje ne bih upravio nikome pojedinačno, upravio bih ga svima. Svi ste uz to što ste teoretičari, istraživači, i nastavnici, i to nastavnici koji na ovaj ili onaj način dolaze u kontakt i s teorijom književnosti i s književnošću samom, ako se to uopće da razdvojiti. Nadovezao bih se na dvije stvari, jednu koju je rekao profesor Oblučar i jednu koju ste rekli vi, profesorice Jukić - ono "lako Francuzima" i dalje a propos te recepcije, mislim, malo banaliziram namjerno. A vi [prof. Oblučar] ste govorili nešto o specifičnoj kombinaciji marksističkog i poststrukturalističkog kod Mrkonjića i kod cijele te generacije. Također o njihovoj kombinaciji proizvodnje književnosti i refleksije o toj književnosti i o takvom tipu proizvodnje koji nije, kao što ste rekli, specifičan samo za njih, nego i za ranije autore, pa, na kraju krajeva, ne samo za naše autore nego i mnogo šire. U kontekstu avangarde, zapravo, cijelo vrijeme imamo posla s tim. Međutim, bila mi je zanimljiva eksplicitna usporedba njihove bliskosti baš poststrukturalizmu i Tel Quelu. A sad, kad se prebacimo u naš nastavni kontekst, naše programe, o poststrukturalizmu i Tel Quelu puno pričamo, jako mnogo, to nam je na neki način temelj teorijskih silaba, vrlo često i temeljni interpretativni alat. A o svim tim autorima, barem imam osjećaj, prvenstveno se govori kao o književnicima. Razmjerno malo dolazi u fokus njihova teorijska refleksija o književnosti i u istraživanju, osobito u našoj konstrukciji silaba, nastave i tako dalje. Ispravite me ako je netočno, imam dojam iz perspektive koja je meni poznata. Imate li neki općeniti komentar na tu situaciju, od svih vas ili tko god je zainteresiran?

Branislav Oblučar: To je slučaj s poezijom iskustva jezika te inzistiranjem na jeziku kao materijalu. $U$ tom se kontekstu stvorila porozna granica između teorije i poezije, što je vidljivo kod kritičara i pjesnika. Sad, koliko je toga doista pročitano, koliko je bio jak izravan utjecaj Tel Quela, to bi se trebalo detaljnije istražiti, ali mislim da je to ostavština avangarde i poststrukturalizma u poeziji. Ideja da je refleksija o književnom djelu, koja ima svoja filozofska i teorijska uporišta, dio samoga djela živa je mjestimice i danas. Zanimljivo je kako se ta žarišta pomiču u regiji. Dok se jezično pjesništvo u Hrvatskoj već 90 -ih godina svojim postupcima uvriježilo, pa donekle i automatiziralo, u Srbiji su upravo takve prakse postale nešto vrlo živo i aktualno zahvaljujući časopisu Pro Femina i urednici i pjesnikinji Dubravki Đurić koja je inzistirala na sprezi poststrukturalističke, odnosno feminističke teorije i 
pisanja poezije te oko sebe okupila grupu mladih autorica. I dok su časopis i poetike koje je promovirao dugo vremena bili na kulturnoj i pjesničkoj margini, danas su to ključna referentna mjesta mlađe i srednje pjesničke generacije u Srbiji, za koju je relevantno i hrvatsko pjesništvo iskustva jezika, kao i ono srpskoga nadrealizma, dakle iskustva avangarde ili onoga što nastaje na njezinome tragu, a prepoznatljivo je upravo po međusobnom zrcaljenju književnog pisanja i teorijskog promišljanja.

Zvonimir Glavaš: Netko od vas - ima želju dodati još nešto?

Tatjana Jukić: Možda samo opaska da je upitno ima li književnost u 20. stoljeću istu ulogu koju je imala u 19. i u 18. stoljeću. Nije li film u 20. stoljeću medij koji radi ono što je radila književnost u 19. stoljeću? I postaje presudan za intelektualnu situaciju revolucije? Možemo li avangardu i revolucije u 20. stoljeću adekvatno zahvatiti bez filma?

Rade Dragojević: Koji bi bio film za Oktobarsku revoluciju?

172 Tatjana Jukić: Oklopnjača Potemkin? Da živi Meksiko? Filmske pripovjedne tehnike u romanu Peterburg Andreja Beloga? Onako na prvu.

Danijela Lugarić Vukas: Tu je zanimljiva Èjzenštejnova pozicija zato što je njegova filmska reprezentacija Oktobarske revolucije ušla u sovjetske udžbenike kao relevantni povijesni prikaz. Kao povijesni događaj Oktobarska revolucija je najbrže i najjednostavnije preuzeta vlast ikad. Dakle, nikad nije bilo takve mase ljudi koji su jurišali kao što je to prikazano kod Ėjzenštejna. Tako da je tu zanimljivo pitanje strahovito važne uloge filma u mitologizaciji Oktobarske revolucije. Onda posebno, naravno, u avangardi kao nadnacionalnoj stilskoj raznolikosti.

Tatjana Jukić: Film je imao vremena od 1895. do 1917. da se razvije. $\mathrm{U}$ to vrijeme i Hollywood već funkcionira.

Zvonimir Glavaš: Hvala. Ima li još netko možda pitanje, nešto na umu, komentar? Ok. Onda predlažem da ovdje zasada podvučemo crtu. Zasada, kažem, jer projekt će se nastaviti dalje sa svojim drugim aktivnostima i drugim fazama, a nadam se da smo ovom tribinom ipak postavili i otvorili mnoga pitanja i, nadam se, ipak dali neke odgovore. Ako ne, pitanja također imaju svoju vrijednost. Hvala vam svima što ste sudjelovali. 
Marina Protrka Štimec: Ja bih isto još jednom zahvalila od srca, pogotovo vama koji ste ostali do kraja, malo se odužilo sve skupa. Mi, naravno, ovdje gdje smo stali s tribinom nastavljamo s našim istraživanjima. Sudionicima tribine hvala na prilozima i poticajima. Naše daljnje aktivnosti na projektu moći ćete pratiti na web-stranici lire.ffzg.unizg.hr i Facebook stranici Lire Hrzz na kojoj će ostati i videozapis ove tribine: https://www. facebook.com/114034199985141/videos/704723586679309/

Još jednom hvala i vidimo se u nekoj od budućih projektnih aktivnosti.

Transkript tribine: Mirela Dakić 